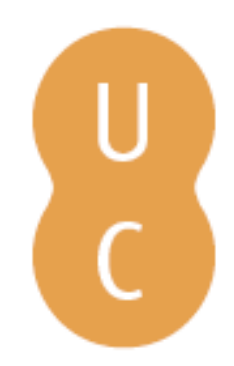

\title{
pกmpalina
}

\section{Platão: helenismo e diferença}
Autor(es):
Azevedo, Maria Teresa Schiappa de
Publicado por: Imprensa da Universidade de Coimbra
URL persistente:
URI:http://hdl.handle.net/10316.2/32396
DOI:
DOl:http://dx.doi.org/10.14195/978-989-26-0393-3_9

Accessed : $\quad$ 26-Apr-2023 10:25:49

A navegação consulta e descarregamento dos títulos inseridos nas Bibliotecas Digitais UC Digitalis, UC Pombalina e UC Impactum, pressupõem a aceitação plena e sem reservas dos Termos e Condições de Uso destas Bibliotecas Digitais, disponíveis em https://digitalis.uc.pt/pt-pt/termos.

Conforme exposto nos referidos Termos e Condições de Uso, o descarregamento de títulos de acesso restrito requer uma licença válida de autorização devendo o utilizador aceder ao(s) documento(s) a partir de um endereço de IP da instituição detentora da supramencionada licença.

Ao utilizador é apenas permitido o descarregamento para uso pessoal, pelo que o emprego do(s) título(s) descarregado(s) para outro fim, designadamente comercial, carece de autorização do respetivo autor ou editor da obra.

Na medida em que todas as obras da UC Digitalis se encontram protegidas pelo Código do Direito de Autor e Direitos Conexos e demais legislação aplicável, toda a cópia, parcial ou total, deste documento, nos casos em que é legalmente admitida, deverá conter ou fazer-se acompanhar por este aviso.

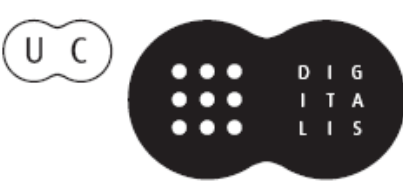




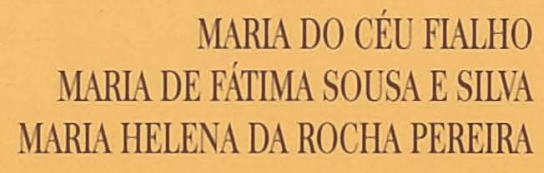

Coordenação

\section{Génese e consolidaç̃ão da ideia de Europa} Vol. I: de Homero ao fim da época clássica 
MARIA DO CÉU FIALHO

MARIA DE FÁTIMA SOUSA E SILVA

MARIA HELENA DA ROCHA PEREIRA

Coordenação

\section{Génese e consolidação da ideia de Europa}

Vol. I: de Homero an fim da época clíssica 


\title{
Coordenação editorial
}

Imprensa da Universidade de Coimbra

\section{Concepção gráfica}

António Barros

\section{Paginação}

Victor Hugo Fernandes

\section{Execução gráfica}

SerSilito - Maia

\section{ISBN}

972-8704-57-7

\section{Depósito Legal}

234088/05

(C) Outubro 2005, Imprensa da Universidade de Coimbra

\author{
Obra PUblicada COM O FINANCIAMENTO DE:
}

Centro de Estudos Clássicos e Humanísticos

$$
\text { FCT Fundaçāo para a Ciência e a Tecnologia }
$$

OBRA PUBLICADA COM O APOIO DE:

FCT: Fundação para a Ciência e Tecnologia - Ministério da Ciência e do Ensino Superior Apoio do Programa Operacional para a Ciência, Tecnologia, Inovação do III Quadro Comunitário de Apoio 



\section{Platão: helenismo e diferença}

Maria Teresa Schiappa de Azevedo

(Universidade de Coimbra)

\section{ATHENAIOI, XENOI E BARBAROI}

\subsection{Estatuto genÉrico NOS Diálogos Platónicos}

O propósito de associar a pesquisa filosófica à realidade do dia-a-dia, onde espontaneamente enraizam os logoi sokratikoi, traduz-se numa apurada recriação da vivência ateniense do séc.V, em que se entrecruzam o apelo à pólis e suas instituições, a consciência de uma unidade grega capaz de sobrepor-se às dissensões de momento e, mais latamente, o sentimento da diferença (não apenas linguística) que opõe os Gregos, no seu conjunto, aos Bárbaros - particularmente os Bárbaros invasores.

Algo da representação esquemática destas três categorias com que quotidianamente Atenas se confrontava - atenienses, gregos não atenienses (xenoi) e bárbaros - está desde logo patente nas fórmulas complementares de identificação, apostas aos nomes próprios das personagens intervenientes ou apenas mencionadas nos diálogos: em especial nos diálogos narrados a um interlocutor (explícito ou não), é observável o intuito de respeitar uma etiqueta de apresentação que, no caso dos cidadãos atenienses, faz acompanhar o nome próprio do nome do pai ou do demos (circunscrição); no caso dos estrangeiros (gregos não atenienses), junta ao nome o indicativo da cidade natal; e, nas raras menções idividualizadas de Bárbaros, especifica a região ou país de que são oriundos ${ }^{(1)}$.

(1) Ocasionalmente, tratando-se de personagens femininas de famílias reais, os nomes 
Um pormenor que neste contexto se afigura relevante é o uso restrito do termo xenos que, embora equivalente à nossa noção de "estrangeiro", cobre apenas os povos gregos de outras regiões que não a Ática e respectivas colónias, não se aplicando, regra geral, ao Bárbaros ${ }^{(2)}$. A razão poderá estar no uso primitivo do termo para indicar especificamente laços de hospitalidade que se estabeleciam entre os membros de uma comunidade e outros fora dela. Tais laços, como se vê pelo episódio de Glauco e Diomedes no canto VI da Ilíada (vv.215-236), abrangeriam ocasionalmente Gregos e Bárbaros, mas razões de afinidade cultural e e em certo aspecto de contiguidade geográfica foram conotando o termo com o tipo de hospitalidade mais comum e passível de reciprocidade - isto é, apenas entre Gregos de Estados diversos. O sentido propriamente político do termo associa-se ao evoluir da autonomia das póleis gregas e da sua organização institucional, acabando de algum modo por concretizar um valor de «diferença» que acompanha as vicissitudes da vida política e os momentos de aproximação ou de divergência entre esses Estados.

No mundo ático e no dos diálogos platónicos, os xenoi são, portanto, os indivíduos oriundos de outras regiões gregas que acorrem a Atenas, ora de passagem - caso dos sofistas Górgias de Leontinos, Protágoras de Abdera ou Hípias de Élis, que intervêm nos diálogos homónimos -, ora para fixarem residência, como o excêntrico par de irmãos, Eutidemo e Dionisodoro, que razões políticas ou outras terão feito trocar Quios, sua cidade natal, por Túrios e, posteriormente, pela Ática (Eutidemo, 271c) ${ }^{(3)}$.

poderiam ser especificados por uma ou mais relações de parentesco: no Alcibíades I encontram-se exemplos (aliás únicos em Platão) deste uso: assim, em 123 c fala-se em Améstris, mãe do actual rei persa, como esposa (viúva) de Xerxes; no que respeita aos reis lacedemónios, o passo 123e -124a menciona Lampido, "filha de Leotíquides, esposa de Arquidamo e mãe de Ágis" - um dos nobres lacedemónios que, a partir de 427/426, partilhou o poder com outro rei de nome Pausânias.

${ }^{(2)}$ Excepto na Lacedemónia. Segundo informa Heródoto (9.11), os Espartanos chamavam também xenoi aos Bárbaros, mas é provável que tal facto tenha significação sobretudo epocal, como assinala J. Ribeiro Ferreira ao salientar que, até inícios do séc. V a.C., os povos não-gregos são designados pelos seus nomes e não por barbaroi: cf. Hélade e Helenos. Génese de um conceito (Coimbra 1993) [daqui em diante: Hélade e Helenos], pp. 220-221.

(3) Quanto ao estatuto genérico dos estrangeiros residentes (metecos), sobretudo em Atenas, vide supra Delfim Leão, "Cidadania e exclusão: mecanismos de gradação identitária". Se exceptuarmos as Leis, o texto platónico ignora praticamente a distinção entre estrangeiros em geral e metecos, motivo pelo qual não nos ocuparemos dela. Uma apreciação do estatuto do meteco através das propostas legislativas da Cidade dos magnetes, nas Leis, pode ver-se em H. Joly, Études platoniciennes. La question des étrangers (Paris, 1992) esp. pp. 44-62. [daqui em diante, La question des étrangers]. 
Nesta exclusão que o termo xenoi (no seu sentido político) determina para os Bárbaros poderá ter influído também o facto de os Gregos serem um povo mais dado a "correr mundo" e a criar laços de hospitalidade fora do seu espaço geográfico, do que a generalidade dos outros povos relativamente à Grécia. Mesmo o cosmopolitismo que Atenas conheceu no seu século de ouro, e depois, raramente terá ultrapassado o âmbito dos povos gregos da Hélade e respectivas colónias. Os diálogos platónicos reproduzem certamente essa realidade, ao limitar a presença de bárbaros ou seus descendentes aos escravos que estão junto dos seus senhores (assim no Ménon), ou aos pedagogos encarregados de acompanhar os filhos destes, $\mathrm{e}$ cujo primitivismo de atitudes e de linguagem não raro deixaria trair a sua origem bárbara. Assim no expressivo final do Lísis: os maus modos com que os pedagogos ignoram as solicitações de Sócrates e dos amigos, no sentido de deixarem os rapazes ficar por mais algum tempo à conversa, correspondem ponto por ponto à linguagem eivada de barbarismos (hypobarbarizontes, 223a) em que se exprimem, sob o calor da irritação (e, provavelmente, do vinho bebido nas festas de Hermes .... $)^{(4)}$.

Há, contudo, nos diálogos sugestões várias de relações de xenia entre cidadãos gregos e bárbaros, em especial o rei da Pérsia (megas basileus ou simplemente basileus, «o rei por excelência»). Um caso ilustrativo é o dos embaixadores, preferencialmente escolhidos, segundo tudo leva a crer, em função de laços de hospitalidade e conhecimentos da língua dos países onde deveriam representar a sua pólis ${ }^{(5)}$. Pirilampo, o tio de Cármides, cujo sucesso como embaixador «junto do Grande Rei e de outros soberanos do continente» é realçado no Cármides (158a), será um dos atenienses a atestar a existência efectiva de relações de xenia, que desde cedo os Gregos terão estabelecido com os habitantes do continente vizinho. Relações que, como

(4) Esse estatuto desvalorizado de elementos bárbaros em Atenas justifica que raramente sejam citados pelo nome ou se indique a proveniência: entre as excepções (não significativas) está o escravo Satyros, pertença de Hipócrates, de que fala o Protágoras (310c) ou a escrava trácia que, no Teeteto, troça do amo, ao vê-lo, entretido a olhar para céu, meter os pés numa poça (para as anedotas de Tales como "filósofo típico", de que o Teeteto é uma das fontes, cf. G.S. Kirk, J.E. Raven e M. Schonfield, Os filósofos pré-socráticos (trad. portuguesa) (Lisboa, 1994) pp. 77-78).

De notar que o estereótipo dos Bárbaros como escravos de "um único homem" deve muito à relação uniforme de senhor/ escravo que era a dos Gregos com os escravos trazidos para a Grécia ou já aí nascidos: cf. J. Ribeiro Ferreira, Hélade e Helenos, pp. 231-232.

${ }^{(5)}$ Cf. Luigi Piccirilli, «La diplomazia nella Grecia antica: temi del linguaggio e caratteristiche degli ambasciatori», Museum Helveticum 58 (2001) 1-31, esp. 8-10. 
também da Ilíada VI (esp. vv. 212-226) se depreende, era transmissível, nos seus direitos e obrigações, aos descendentes. Em tom jocoso, o Ménon assinala este laço hereditário, igualmente respeitado, tanto quanto pode supor-se, por Gregos e Bárbaros: ao ouvir o seu interlocutor definir a "virtude" em termos de "ouro, prata, cargos e honras na cidade», Sócrates insinua que ele não estará a falar como um grego e sim na qualidade de «hóspede hereditário do Grande Rei» (78d) - como tal, obrigado a defender os interesses e as convicções deste.

O mesmo diálogo proporciona um trocadilho de efeito menos visível à volta de xenos. Em 89e, quando Ânito se junta aos dois interlocutores principais, Sócrates solicita a sua ajuda, lembrando ser Ménon seu hóspede (xenos); no final, é a Ânito que o termo xenos (agora, no sentido de hospedeiro) reverte, mas em contexto ambíguo, que permite a leitura de um Ânito «estranho" à sua cidade e capaz mesmo de a prejudicar, por via dos sentimentos de ira que o decurso da conversa com Sócrates foi alimentando: «Quanto a ti, Ménon, convence lá o teu hospedeiro (xenos) Ânito dessas mesmas ideias, a ver se ele se torna mais tratável; se o convenceres, é matéria em que prestarás também serviço aos Atenienses» (100b-c). A intenção parece clara, se nos lembrarmos de que Ânito foi justamente o principal acusador no processo movido contra Sócrates ...

\subsection{O testemunho do Crátilo}

Que a distinção entre xenoi e barbaroi tem em Atenas um sentido primacialmente linguístico mostra-o o teor calculadamente objectivo da discussão sobre a linguagem no Crátilo: há um elo natural (physis), comum a Gregos e Bárbaros, entre as coisas designadas (pragmata) e o sinal fónico que as exprime (onomata), como pretende Crátilo, ou é esse elo inteiramente dependente de um acordo e convenção (nomos), susceptível de se estabelecer ou quebrar, de pessoa para pessoa, como de cidade para cidade ou de povo para povo? Hermógenes, defensor desta última posição, observa pertinentemente: «reparo que cada cidade grega tem por vezes designações específicas para as mesmas coisas, divergindo assim Gregos dos restantes Gregos, tal como os Gregos dos Bárbaros» (385d-e).

Abstraindo dos inúmeros problemas de interpretação do diálogo, a substância das reflexões sobre a linguagem, com relevância para este tema 
(sobretudo, a primeira série de etimologias, na conversa com Hermógenes), centra-se no grego contemporâneo de Platão - a hellenike phone no seu amplo conjunto, formada pelo ático e pelos falares não áticos ou "estrangeiros", em oposição clara ao mundo bárbaro.

Merecem destaque alguns aspectos genéricos que apontam, quer para uma procura de universalidade no âmbito do binómio grego/ bárbaro, quer para a compreensão e superação das diferenças, na oposição attikon/xenon, concretizando esta última uma posição que, regra geral, é apelo comum nos diálogos:

1. Ao contrário do que ocorre no plano político, social e ético, não há, no domínio da linguagem, qualquer sugestão de superioridade de Gregos ou Bárbaros: pondo de parte o papel activo de um legislador ou nomóteta (nomothetes), igual ou diferente para Gregos e Bárbaros, a observação de que a linguagem de uns e outros - embora variando na sua representação material (fonemas e sílabas) - tem igual eficácia na sua função de "indicar as coisas" (390 a), corresponde certamente a uma ideia consensual que se vai impondo, com a implementação do estudo científico da linguagem, particularmente por via dos sofistas.

A ausência de conhecimentos linguísticos das linguagens bárbaras leva a que Platão evite referir um plural ou um singular (barbaroi aplica-se apenas a povo ou povos, e.g. 409e). No sentido de contornar essa dificuldade, recorre-se geralmente a uma perífrase "algo de bárbaro" (barbarikon ti), como sucede a propósito de pyr "fogo" em 410a, termo que não tem explicação na língua grega e se considera importado do frígio ${ }^{(6)}$.

De notar que no Protágoras, onde não se põem iguais exigências de rigor, Platão refere explicitamente a possibilidade de "uma língua bárbara" ter levado Pítaco a usar, num sentido indevido, o termo khalepos: "como lésbio que era, alimentado numa língua bárbara" (en phonei barbaroi, 341c). No passo há um óbvio sentimento de rejeição ao fenómeno, provavelmente frequente, de contaminação linguística, nas regiões onde os Gregos

(6) O frígio é a única língua bárbara que Platão nomeia no Crátilo: cf. L. Méridier na sua Notice à edição do diálogo (Platon, Oeuvres complètes t.V, Paris, Les Belles-Lettres, 1969, p.19, n.2) onde se refere, em abono da hipótese, a forma hyr (“fogo”) em arménio. Pode supor-se, no entanto, que tenha sido o frígio a adoptar (do arménio ou do hitita, se se atender à contiguidade geográfica) um vocábulo cuja raiz os confrontos com o osco, o hitita e o báltico, entre outros, mostram hoje pertencer ao indo-europeu: vide P. Chantraine, Dictionnaire étymologique de la langue grecque (Paris, 1968) s.v. pyr, p.197. 
convizinhavam com os Bárbaros. O Crátilo não manifesta tal preconceito e não mostra embaraço mesmo em aventar que uma língua bárbara pudesse ter sido a fonte das palavras gregas, primitivas ou não (409d-e).

2. O diálogo considera que, num estádio remoto, o "grego" e o "bárbaro" podiam não ter diferenças tão consideráveis. Esta sugestão, que pretende sublinhar uma estrita objectividade no âmbito da especulação linguística, insinua-se, no início, com as referência aos nomes que os Troianos davam ao seu principal herói e ao seu filho, respectivamente Heitor e Astíanax: não só são nomes "que se assemelham aos gregos"(tois hellenikois eoiken, 393a), como têm perfeita explicação dentro da língua grega ${ }^{(7)}$.

No final do seu excurso sobre as "palavras primitivas" (prota onomata), inexplicáveis devido à sua antiguidade, Platão não exclui a hipótese de elas provirem "de alguns dos Bárbaros” (425e) e de estes serem, consequentemente, mais antigos que os Gregos... Com esta ideia algo ousada, Platão tem, sobretudo, como alvo precisar o termo "bárbaro" na sua acepção mais neutral: "aquilo que não se conhece (ou não se entende)" - 421c-d.

O Teeteto ilustra, de forma muito expressiva, esta assimilação mais ou menos consciente de "bárbaro" a "não-conhecido" ou "não-compreendido". Quando Teeteto apresenta a sua definição de conhecimento como sensação, Sócrates rebate-o com a seguinte pergunta: "Antes de aprendermos a língua dos Bárbaros, dizemos que não estamos a ouvir os sons que eles produzem ao falar, ou que estamos a ouvir e a compreender o que eles dizem?"(163b).

3. Na mesma proporção em que "bárbaro" (barbarikon) é o "não-conhecido" ou "não-compreendido”, o grego é, no domínio da língua, o que se conhece e pode ser compreendido. A línguagem ática (attike), como as linguagens "estrangeiras" (xenikai), integram-se num conjunto mais amplo que é a língua grega (hellenike phone - 409e).

(7) Foi uma constatação que intrigou pensadores e historiadores do séc. V a.C.. Platão segue neste ponto Tucídides, que afirma não haver ainda ao tempo de Homero distinção entre Helenos e Bárbaros (Livro I:1.1; 5.1; 6.1 e 6; Livro VI: 18.2). Para outros pormenores vide J. Ribeiro Ferreira, Hélade e Helenos, esp.pp. 444-445.

Numa fase platónica posterior, o Crítias oferece, em contexto semelhante (a propósito da Atlântida) uma explicação mais verosímil: os nomes gregos, aplicados a Bárbaros, são tradução de Sólon, a partir do significado dos nomes "atlantes" fornecido pelos sacerdotes do Egipto. Os Egípcios haviam por sua vez traduzido na sua língua os nomes "atlantes”. Eventualmente, o Crítias remete para a perplexidade levantada no Crátilo a propósito dos nomes gregos que Homero atribui a grande parte dos heróis troianos. 
$\mathrm{Na}$ seç̧ão das etimologias - independentemente da seriedade que se lhes atribua ${ }^{(8)}$-, Platão põe em campo um riquíssimo jogo de relações e correspondências, revelador de uma larga prática dos falantes das várias línguas ou dialectos em se entenderem mutuamente ${ }^{(9)}$. Na especificação e racionalização de muitas dessas diferenças, está implícito o objectivo de promover a consciência de uma unidade essencial da língua grega, face às dos Bárbaros. O ático (attike phone) está, nesta perspectiva, em absoluta igualdade face aos outros falares não-áticos (xenikai), cujas variantes são por vezes preferidas ou citadas como também adequadas. Podem mesmo complementar-se, como sucede na inventiva etimologia do nome de Zeus, de que uns falares retêm uma metade da significação e outros, a outra metade... Ou seja, "aquele através (Dia) do qual vem a vida (Zen)" - cf.396a-b.

4. Ao longo das várias análises sobressaem, para além desse fundo pretendido de identidade estrutural de uma só lingua, várias observações intuitivas que a linguística actual, após a descoberta do indo-europeu, confirma: assim, a alternância grau o/ grau e, talvez não aplicável no caso de soma/sema mas indubitavelmente presente nas reflexões sobre as variantes do substantivo de eimi (ousia/essia/osia, 401c-d); a alternância grau o/ grau zero, que legitima a equivalência etimológica entre o elemento homo- e o alfa copulativo, a propósito do nome de Apolo (405c-e); o intercâmbio entre formas com vogal inicial aspirada e não aspirada (por psilose), bem como alfa (breve ou longo) e eta. Um dos efeitos mais curiosos deste jogo linguístico é a legitimidade de se poderem interpretar em sentidos diferentes ou até opostos palavras iniciadas por a-, que tanto pode representar um alfa privativo como um alfa copulativo, como ocorre na explicação do nome Hades ("não-visível ou "que tudo conhece", 403a-403b).

5. Toda esta gama de possibilidades interpretativas, em que os pontos de referência se multiplicam em função de diversas formas e usos de um mesmo onoma, representa uma homenagem à língua grega no seu conjunto

${ }^{(8)}$ Uma reavaliação positiva desta problemática, fundamentada em critérios mais flexíveis de significado, pode ver-se em D. Sedley, "The etymologies of the Cratylos", JHS 118 (1998) 140-154.

(9) A que não é alheio o carácter compósito, artificial, da linguagem literária, desde Homero. Sobre o sentimento de uma "língua comum" que leva os Gregos a autodefinirem-se como homoglossoi "falantes de uma mesma língua”, cf. J. R. Ferreira, Hélade e Helenos, esp. pp. 116-124. 
e à sua riqueza de meios expressivos. Terá sido provavelmente para sublinhar a igualdade de contributos de todos os falares gregos nessa língua comum, a hellenike phone, que Platão se abstém de os individualizar (com a excepção inevitável do ático, "a nossa bela língua”, como ironicamente diz em $418 \mathrm{~b}$, e da referência a uma forma específica do tessálico, no caso um onoma correspondente a "o pensamento da divindade" (he theou noa, 407b) teve o cuidado de lhe dar a forma definitiva ... com um alfa "estrangeiro" (alpha xenikos).de Apolo). Mas, para afastar tentações compreensíveis de pleonexia, mesmo num domínio volátil como o da linguagem, o nomóteta, ao figurar para a deusa Atena um onoma correspondente a "o pensamento da divindade" (he throu noa, 407b), teve o cuidado de lhe dar a forma definitiva ... com um alfa "estrangeiro" (alpha xenikos).

\section{Sócrates face ao binómio Atenas/ Estrangeiros}

\subsection{Sócrates E Atenas}

À excepção da conversa directa do Fédon, que tem como local Fliunte (cidade do noroeste do Peloponeso) e das Leis, expressamente situadas em Creta - o único diálogo sem a interveniência de Sócrates, substituído por um anónimo «Estrangeiro Ateniense» — os diálogos platónicos têm invariavelmente como cenário explícito ou implícito Atenas ou locais próximos. Está neste caso a República, cuja conversa decorre no regresso do Pireu a Atenas; e a zona rural, ao longo do rio Ilissos, fora já das muralhas da cidade, onde Fedro, no diálogo homónimo, procura com Sócrates o alívio para um dia de calor abrasivo.

Este último passo contém uma observação emblemática: o apego de Sócrates à sua cidade é tal que raramente transpõe as suas muralhas para usufruir da beleza e da amenidade do campo. $\mathrm{E}$ isto, "porque o campo e as árvores" nada lhe "ensinam" (230d).

De facto, é no convívio espontâneo com os conhecidos (ou mesmo desconhecidos) que se cruzam diariamente no seu caminho que Sócrates testa a aquisição possível da sabedoria humana, a pesquisa dos valores pelos quais tanto a sociedade como o indivíduo devem reger-se. Só no espaço habitado e familiar de Atenas faria sentido essa permanente atitude 
de inquirir, com os contornos provocatórios ou, no mínimo, heterodoxos que lhe atribui a Apologia (e.g. 21c-d). Atitude que consigna a reversão, não apenas do tradicional elo mestre/ discípulo com também das metas do saber: pela primeira vez, como diz Cícero, a filosofia desce "dos céus às moradas dos homens" (Tusculanas $V, 4.11$ ).

Mas não é somente a impossibilidade de concretizar, noutra parte qualquer, um magistério sui generis que prende Sócrates a Atenas. Quando, no Críton, o velho amigo de infância o interpela e incita à fuga, lembrando-lhe a obrigação de combater a injustiça de que fora vítima e assegurar a educação dos filhos menores, Sócrates confronta-o com o fictício discurso que as Leis lhe dirigiriam no momento da fuga. Trata-se da famosa Prosopopeia das Leis onde, sem custo, se vislumbra a personificação da própria Atenas (e que serviu de inspiração a Cícero na idêntica Prosopopeia da Pátria, nas Catilinárias I,18 ): “fomos nós que te gerámos, que te educámos e alimentámos” - 51c.

A linguagem mítica da autoctonia, que celebra nos Atenienses os descendentes directos da Terra-Mãe ateniense (como longamente se explicita no Menéxeno) repercute-se na vivência peculiar do cidadão que Sócrates foi e recusa deixar de ser. A ligação do indivíduo à sua pátria não é a do mero compromisso legal de acatar as suas leis em troca dos direitos que ela lhe concede, é antes a de um parentesco assumidamente biológico, que a referência a ekgonon "cria", "rebento" reitera. Nesta medida, ainda que, na sua aplicação prática e por erro humano, as leis possam falhar, nem por isso deixam de ser o suporte material e visível de um vínculo a que se reconhece uma natureza sagrada (timioteron ... semnoteron kai hagioteron, 51a), não diverso daquele que impõe aos filhos o dever de estimar e venerar os pais.

Numa interpretação verosímil com a realidade histórica, Platão dá voz às Leis para lembrar quão forte é esse sentimento em Sócrates: excepto em serviço militar, apenas uma vez saiu da cidade para assistir a festividades no Istmo; o desinteresse por conhecer outros espaços geográficos e experienciar outros regimes políticos (para mais, dada a preferência manifestada - pelo menos em teoria - por constituições, como as de Esparta ou Creta, 52e) tem a sua razão de ser num apego enraizado ao solo de Atenas e ao seu viver quotidiano - apego em que Sócrates avulta dos demais atenienses (diapherontos, 51b).

Não obstante a força desse vínculo, paradigmaticamente centrado em Sócrates, há uma particularidade que as Leis pertinentemente evocam pro 
domo sua: ele só se torna efectivo, moralmente irrecusável, com a adesão voluntária que cada cidadão manifesta, ao iniciar o exercício dos seus direitos (e deveres) de cidadania; mesmo depois, a opção por outras instituições - por outra "pátria", conforme a simbiose explicitamente estabelecida - é uma opção em aberto, desde que por acordo mútuo. Assim a decisão da fuga, a recusa de Sócrates em submeter-se ao veredicto que o condenara, jamais redundaria em benefício da justiça e antes na destruição das leis, como resulta do passo 52 d-e:

E agora não te envergonhas dessa linguagem, deixas de fazer caso de nós, as Leis, e intentas destruir-nos procedendo como o mais vil dos escravos? Quebras os acordos e os compromissos havidos connosco? (sunthekas... kai homologias).

A par de testemunho biográfico, o Críton sintetiza assim a expressão de uma elaborada consciência cívica, cuja complexidade associa a ideia instintiva de "pátria" como "lugar" dos antepassados (patris) ao regime político que a concretiza - a democracia. Embora com traços comuns a outros regimes antigos, é em Atenas que o debate sobre a cidadania ganha contornos actuais, em particular pela noção da homologia (acordo) entre o indivíduo e o Estado, que está subjacente às democracias surgidas e aperfeiçoadas na Europa, nos últimos séculos.

É provável que tenhamos aqui o contributo específico de Atenas para uma reflexão sobre a cidadania e a correlativa noção de Estado, que as invasões persas, nas primeiras décadas do séc-V a.C., e a guerra do Peloponeso, nas últimas, vieram sedimentar; a que poderia juntar-se, na situação-limite que motiva o Críton, o princípio socrático de que é preferível sofrer a injustiça a cometê-la. No quadro de um "Estado de direito" como é o das Leis do Críton ${ }^{(10)}$, apenas se reconhece uma via para contestar as suas decisões: a da persuasão, através dos mecanismos legais admitidos para tal (51b, 52c). Incapaz de persuadir Atenas da injustiça da sua condenação, Sócrates prefere sofrê-la a atentar contra as suas leis.

(10) Esta perspectiva do diálogo é expressivamente realçada por Wilamowitz em Staat und Gesellschaft, que citamos em tradução inglesa: "Nowhere in Greek Literature does the fundamental sovereignty of law appear in a more striking form that in that passage of the Criton ". (apud A.W. Gomme, "Concepts of Freedom" in More Essays in Greek History and Literature, London,1962, p. 145). Tal perspectiva, como se esclarece no estudo citado, não colide com a escolha individual - proairesis. 


\subsection{Sócrates E XeNOI}

Não obstante a fixação de Sócrates a Atenas, o cosmopolitismo da cidade justifica o repetido alargamento dos diálogos socráticos a personalidades não atenienses (xenoi), que então passavam por ser expoentes da vanguarda cultural do mundo grego - em especial os sofistas: Górgias de Leontinos, Protágoras de Abdera, Hípias de Élis, Pródico de Ceos, entre outros.

Embora enquadradas numa moldura ficcional, tais conversas reproduzem certamente a curiosidade insaciável de Sócrates, não só por saber o que os outros Gregos pensavam, mas sobretudo por aferir o valor real do saber (sophia) que cada um julgava possuir. Três dos sofistas citados dão mesmo nome a diálogos platónicos, nome eventualmente duplicado, a aceitar que o Hipias maior seja platónico e não obra, por exemplo, de um discípulo ${ }^{(11)}$.

A recriação platónica tem a ver, neste ponto, com uma amplitude de relacionamentos entre atenienses e xenoi que faria sem dúvida parte do quotidiano de Sócrates como, também, da cidade em geral. O respeito pela verosimilhança histórica poderá mesmo ir mais longe em Platão do que em Xenofonte: Pródico, várias vezes referido como "mestre" de Sócrates (Protágoras 341c, Crátilo 384b-c) não é jamais, ao contrário do que acontece nos Memoráveis, sujeito ao crivo da inquirição socrática. A referência amigável ao "meu amigo Pródico", no Protágoras (ho hemeteros etairos, 282c), corroborada pela cumplicidade com que este acompanha os malabarismos semânticos de Sócrates no sentido de confundir Protágoras, explica suficientemente a sua exclusão, no obra platónica, como interlocutor (e adversário) privilegiado, em oposição ao que sucede com os outros três sofistas. O contacto, apenas episódico, com estes permite um confronto intelectual e ético por vezes violento: não é o caso do Protágoras (onde a imagem do sofista sai de algum modo beneficiada), mas é certamente a do Górgias, onde a questão do justo e do injusto se cifra numa radical incompatibilidade, alimentada não tanto pelo autor do Elogio de Helena quanto pelos discípulos Polo e Cálicles, que lhe sucedem na discussão

(11) Veja-se a minha Introdução a Platão, Hípias Maior (Lisboa, 1999) pp. 11-18. Embora o diálogo seja referenciado por Trasilo como autêntico, aspectos vários de conteúdo e estilo, em grande parte sistematizados por Tarrant, fazem-me pender para a sua não autenticidade. 
- representantes, como o Trasímaco do livro I da República, de uma nova geração de discípulos ${ }^{(12)}$, mais aguerrida e emancipada, no que toca a (pre)conceitos morais vigentes, que os seus mestres hesitavam ainda em beliscar.

Outros xenoi, alguns provavelmente residentes em Atenas por um período significativo, são integrados numa relação afectiva mais próxima de Sócrates. Para além do Críton, o Fédon é o diálogo em que melhor se dá conta de um círculo pan-helénico de amigos onde, a par de atenienses (cuja referência vemos por duas vezes, neste diálogo e na Apologia, alargar-se ao próprio Platão $\left.{ }^{(13)}\right)$, se enumeram estrangeiros oriundos das mais diversas partes de Grécia: além de Fédon de Élis, também Euclides e Térpsion de Mégara, e Fedondes, Símias e Cebes de Tebas - estes dois últimos, aliás, os principais interlocutores de Sócrates na discussão. Mencionam-se ainda apenas pelo nome, embora não estando presentes, Aristipo de Cirene e Cleômbroto de Ambrácia (cf.59b-c). Num estatuto cénico, aliás, incomum em Platão, o diálogo directo, que inclui a narrativa do último dia de Sócrates (em Atenas) decorre na realidade em terra estrangeira, concretamente em Fliunte - pequena cidade do extremo oeste do Peloponeso -, e é motivada pela curiosidade que Equécrates, um dos seus nativos, mostra em informar-se dos acontecimentos, já que nenhum estrangeiro (xenos) vindo de Atenas soube dar deles notícia concreta (57a-b).

Apesar das escassas saídas de Sócrates fora do território ateniense (saídas, além do mais, sem significado cultural ou filosófico) estas referências comprovam a ideia de uma personalidade conhecida no conjunto dos Estados helénicos, sem dúvida pelo estreito convívio com estrangeiros (xenoi) que a vida de Atenas lhe proporcionava e a que o Menéxeno faz referência, ao falar dos elogios oficiais: "como de costume, acompanham-me sempre alguns estrangeiros que os escutam" (235b). Esse círculo pan-helénico de amizades (que se estende, no Críton, aos amigos dos amigos que estão dispostos a acolher Sócrates no exílio) não é certamente um exagero de Platão: a continuidade do seu magistério, para além do que os diálogos de Platão e de Xenofonte testemunham, é reclamada por discípulos, conhecidos

(12) Não necessariamente sofistas profissionais: J. de Romilly traça com subtileza a fronteira entre os "profissionais" (que a necessidade de apoio popular limita) e os homens ricos, como Cálicles, que podem dar-se ao luxo de um aproveitamento puramente pessoal das doutrinas sofísticas: cf. Les grands sophistes de l'Athènes de Périclès (Paris, 1988) esp. pp. 210-217.

${ }^{(13)}$ Cf. Ap. 34, a, 38 b e Phd. 59 b. 
por "socráticos menores", que estão na base de quatro principais escolas filosóficas: a Cirenaica, ou hedonística, fundada por Aristipo de Cirene; a Megárica, por Euclides de Mégara; a Elidense-Eritriense, por Fédon de Élis e Menedemo de Erétria; e a Cínica, fundada por Antístenes.

Destes últimos citados, apenas Antístenes era ateniense; e não será inverosímil que, num ou noutro caso, tivesse sido a própria fama de Sócrates a atrair estrangeiros conhecidos a Atenas, como se conta que sucedeu com Aristipo $^{(14)}$.

\section{Diálogos Platónicos da $1^{\mathrm{a}}$ e $2^{\mathrm{a}}$ FASE:}

\subsection{Atenas no ConteXto helénico}

\subsubsection{Menção genÉrica de outros Estados gregos}

O Críton e o Menéxeno são os diálogos mais ricos em referências conjuntas a outros povos ou Estados gregos. O primeiro deles dá uma ideia geral das opiniões dominantes em Atenas sobre as constituições de algumas principais póleis. De acordo com essa ideia geral, que é expressa na Prosopopeia das Leis, Creta e a Lacedemónia são Estados morigerados (eunomo - - sem que, contudo, Sócrates tivesse preferido qualquer deles para aí viver(52e); também Tebas e Mégara se caracterizam por boas constituições, responsáveis pelo elevado nível cívico dos seus cidadãos - o que inviabilizaria a hipótese de qualquer ateniense, fugido às leis de Atenas, aí ser bem-vindo (53b); finalmente a Tessália, onde as possibilidades de Sócrates ser bem acolhido são mais consistentes, apenas tem para oferecer uma vida negligente no tocante à justiça e às leis (53d). A referência adicional que se faz ao facto de Sócrates poder somente aí educar os seus filhos como "estrangeiros" (xenoi) é um óbice que valeria para qualquer outro Estado.

Outra é a perspectiva do Menéxeno, onde o elogio de Atenas acompanha parte de sucessos comuns a toda a história de Grécia. Ultrapassando o quadro mítico de primitivas guerras contra Eumolpo e as Amazonas, e do papel de Atenas na defesa dos Argivos contra Tebas e dos Heraclidas contra

${ }^{(14)}$ W.K.C. Guthrie, Socrates (Cambridge, CUP, 1971) p. 170. 
Argos (239b), as referências mais concretas têm a ver com as invasões persas e com as guerras civis que se seguiram. No contexto das primeiras, o aspecto que mais se destaca é a inércia e o receio de todos os povos gregos face à invasão, ordenada por Dario, que teve por alvo directo os Eritrienses e os Atenienses (240c-d). Dessa acusação excluem-se os Lacedemónios, que efectivamente compareceram, embora atrasados, e que deram apoio efectivo dez anos mais tarde, em Plateias. No seguimento das guerras civis que se desencadeiam pela hegemonia sobre a Grécia, e que têm como principais protagonistas Atenas e Esparta, referem-se Estados apanhados nessa guerra cruzada: a Beócia, que os Atenienses libertaram dos Lacedemónios (242b); numa fase já posterior, os Leontinos, cujo pedido de auxílio levou Atenas à expedição frustrada da Sicília (242e-243b-c); Argivos, Beócios e Coríntios são referidos entre os primeiros povos que pedem auxílio a Atenas quando a Lacedemónia os ameaça com o seu poderio - para mais tarde capitularem perante o Grande-Rei. No conjunto, os povos efectivamente dotados de coragem e energia para fazer face ao inimigo comum são Lacedemónios e Atenienses mas (na óptica do discurso ...) sobretudo estes, a quem as inimizades deixaram várias vezes isolada e obrigada a enfrentar sozinha o poderio asiático $(245 \mathrm{a})$.

A coerência da postura ateniense face aos Bárbaros complementa-se no Menéxeno por princípios superiores de humanidade e tolerância com os restantes povos gregos, de que é paradigmática a atitude de Atenas em Esfactéria, ao libertar sem condições os generais lacedemónios vencidos e aprisionados, em vez de os executar, como seria seu direito numa guerra "normal" (242c-d). Mesmo sendo óbvio que essa postura não foi uniforme, e não evitou a responsabilidade activa por atrocidades cometidas durante a Guerra do Peloponeso (que o discurso omite...), não é menos certo que à vivência cívica e cultural de Atenas se deve uma nova ética nas relações (mesmo hostis) entre Gregos.

São os poetas, oradores e pensadores de Atenas que se empenham na distinção clara entre "dois tipos de guerra", de finalidade e limites éticos diversos: enquanto a guerra contra os reais inimigos (os Bárbaros) encoraja o prosseguimento da luta até à destruição completa do adversário, as guerras entre Gregos, como discórdias civis que são (staseis), e não guerras no seu verdadeiro sentido, devem pautar-se por estritas normas de generosidade para com o adversário vencido. Esse é também o princípio que passa à República, mas sem a visão idealista do Menéxeno (como de outros discursos 
de louvor a Atenas $\left.{ }^{(15)}\right)$. Após Sócrates distinguir entre guerras nacionais (staseis) e estrangeiras (polemoれ), e as diversas normas que as deverão reger, Gláucon dá o seu apoio, num comentário crítico de que Atenas não está excluída $(471 \mathrm{~b})^{(16)}$.

\subsubsection{LACEDEMÓNIOS}

Do conjunto dos povos gregos mencionados, destacam-se os Lacedemónios que representam, no panorama do séc.V a.C. helénico, o outro pólo de garantia da liberdade dos Gregos face aos Bárbaros. A Guerra do Peloponeso veio apenas confirmar que a hegemonia política e espiritual, reclamada por Atenas à sombra da vitória contra os Persas era, na verdade, uma hegemonia repartida - e disputada - com Esparta.

Deste modo, os pressupostos políticos e educacionais que asseguram a manutenção dos valores e costumes da sociedade espartana (primacialmente centrados na defesa so território e das suas instituições) tornam-se alvo crescente de curiosidade, polémica e, não raro, apreço. Platão sugere com clareza a existência de uma corrente laconizante em Atenas, eventualmente mais activa do que a simples admiração pelo regime e pelas instituições espartanas que Sócrates no Críton parece tributar-lhes. É neste ponto expressiva a atitude representada por Laques, no diálogo homónimo, não apenas ao recusar a hoplomaquia, na base de que também os Lacedemónios lhe não reconhecem interesse na actividade guerreira, mas sobretudo no plano moral: o homem que cria "acordo entre as palavras e acções" é "igualzinho a um músico que criou a mais bela melodia, não /.../ à maneira iónica nem, em meu entender, à maneira frígia ou lídia, mas exactamente à maneira dórica, aquela que constitui a única harmonia helénica" $(188 \mathrm{~d})^{(17)}$. A menos que seja fruto de reflexão independente, esse dado socrático (e

${ }^{(15)}$ Aspecto que será desenvolvido no 2. ${ }^{\circ}$ volume dos estudos dedicados a esta temática.

(16) "Eu por minha parte, concordo que é assim que os nossos cidadãos devem comportar-se com os seus adversários. Com os Bárbaros, devem proceder como actualmente os Helenos uns contra os outros (471b)”. Trad. de Maㅗ Helena da Rocha Pereira, Platão. República (Lisboa, 9/2001) p. 247.

(17) Trad. de Francisco de Oliveira, Platão. Laques (Lisboa, 1987) p. 52. Sobre a personagem (que comandou com Sócrates a retirada de Délion - cf.181b), veja-se a Introdução à edição citada do diálogo, pp. 25-28. 
epocal) prolonga-se, quer em Xenofonte quer em Platão ${ }^{(18)}$, que tanto na República como Leis adopta vários pressupostos educacionais e legislativos implícita ou explicitamente inspirados em Esparta.

Não é improvável que o desgaste que a democracia ateniense foi sofrendo, após os anos de glória de Péricles, tenha a ver com uma apreciação crescentemente positiva das instituições espartanas. Quando em Atenas se refere a eunomia, isto é, a perfeição legislativa capaz de promover a justiça e a harmonia social, não são já as leis de Sólon e sim as de Esparta que se tomam como modelo; o que justifica a conotação de "conservadorismo" que os detractores foram imprimindo ao uso do termo, captando nele a conhecida aversão por toda a espécie de inovações que caracterizava a sociedade lacedemónia.

Ambos os valores coexistem na referência incidental do Hípias Maior, onde Sócrates confronta o sofista com o facto de um Estado "morigerado" (eunomos, 283d) como a Lacedemónia manifestar absoluto desinteresse pelas novidades científicas e culturais que o sofista traz para "vender": deste, acolhe apenas de bom grado as tradicionais histórias de um passado mítico em cujos conceitos de heroísmo e de "virtude" (arete) se revê(19).

Em sentido idêntico vão as considerações de Pausânias, o segundo conviva de $O$ Banquete a tomar a palavra. A pederastia fornece aqui o mote para marcar uma reflexão sobre a diversidade dos nomoi ("leis" mas também "regras sociais") vigentes em Atenas e Esparta (182 a sqq.). Entre a aceitação sem reservas que o nomos espartano estipula (bem como na Élide e na Beócia), e a condenação in limine, reportada a grupos de Iónios e outros, mais afins aos Bárbaros ${ }^{(20)}$ - que vêem na pederastia a maior ameaça aos seus regimes tirânicos $(182 \mathrm{~b}-\mathrm{c})$ - o orador exalta a flexibilidade do nomos ateniense, onde são primacialmente tidos em conta valores de ordem espiritual e ética. De acordo com eles, a pederastia é aceite se visa a arete (na sua duplicidade de "virtude" ou "excelência", intelectual e social); ou é condenada, se se limita à simples satisfação do prazer físico, desenquadrada de qualquer meta espiritual.

${ }^{(18)}$ Sobre Xenofonte, cf. infra pp. 54-57 e respectivas notas.

${ }^{(19)}$ Esse deslize semântico de eunomia é destacado por V. Ehrenberg, "Eunomia" in: Aspects of Ancient World (New York, 1973) pp. 70-93. Para o valor de nomos ("lei” mas também "norma social”) que a seguir ocorre vide a análise pormenorizada de J. Ribeiro Ferreira, Hélade e Helenos, pp. 155-190. Cf. a nossa edição do Hípias Maior, citada na nota 10, esp. pp. 116-117.

(20) Pausânias invoca, numa perspectiva, aliás, tradicional, o exemplo de Harmódio e Aristógiton, que derrubaram os Pisístratos em Atenas, pagando com a vida o ódio ao regime tirânico a que Atenas foi sujeita sob o domínio desta dinastia. 
O esquematismo da repartição remete-nos para o contexto de questões candentes no debate político que os Atenienses instalaram no seu quotidiano; em causa está a superioridade relativa dos dois regimes gregos mais em evidência, após a vitória sobre os Bárbaros - problemática a que a Guerra do Peloponeso veio dar plena projecção.

Pausânias (e com ele teremos de supor uma larga facção da classe dominante) toma partido claro pela democracia atenienese contra o regime fechado e culturalmente estreito de Esparta - como, noutra perspectiva, contra os regimes tirânicos dos Bárbaros. A aparente objectividade do seu excurso legislativo não esconde, a uma análise mais funda, a "tacada" que pretende lançar-se no campo da facção pró-lacedemónia, de algum modo veiculada no discurso de Fedro, o orador antecedente. À excelência de uma sociedade guerreira, de inspiração espartana (que culmina no apelo a um "exército de amantes e amados" - 178e) contrapõe Pausânias o estigma de uma incapacidade cultural para conquistar de facto a arete, simbolizada na arte de persuadir um jovem a iniciar uma relação amorosa: por isso, a pederastia é aceite sem mais entre povos, como os Lacedemónios, onde não há pessoas dotadas do dom da palavra (sophoi legein), e, logo, incapazes de persuadir os jovens $(182 \mathrm{~b}, \mathrm{~d})$.

O proverbial laconismo dos Espartanos, convenientemente equiparados por Pausânias aos Elidenses e aos Beócios - estes últimos, conhecidos pela sua emblemática "estupidez" - torna-se assim num alvo preferencial de ataque às instituições (nomoi) de Esparta. Não significa, contudo, que o argumento colha desprevenidos os defensores do modelo lacedemónio em Atenas. Numa sociedade desgastada pelo "poder da palavra", tantas vezes errada e inconfessadamente usada contra os interesses da pólis, o "estilo lacónico", reportável aos Espartanos, pode pelo contrário jogar como indicativo seguro de "sabedoria" ${ }^{(21)}$ e, implicitamente, da real eunomia das suas instituições - mais assente na pragmática dos actos do que dos discursos.

É, contudo, pelo lado paródico que Platão desenvolve esta linha argumentativa no Protágoras (342c-343b). Contra o pensar comum, Sócrates sustenta aí que o amor pela sabedoria (philosophia, 342e) teve a sua origem

(21) Não é certamente por acaso que o jogo etimológico do Crátilo associa sophia ao nome próprio Soos, “- termo que os lacedemónios usavam comummente para "impulso rápido”. Sophia terá nesse contexto o valor etimológico de "contacto com o movimento (rápido)" - 412b. 
mais antiga em Creta e na Lacedemónia; se os actuais descendentes aparentam ignorância ou incapacidade de expressar-se, tal deve-se apenas a uma simulação táctica: não lhes convém exibir diante de outros Gregos a sua supremacia num domínio que eles prezam mais do que a arte de guerra - o da sabedoria (sophia). Daí, portanto, a relutância em permitir a entrada de estrangeiros na sua cidade ou em deixar sair os seus jovens...

Neste entendimento "oximórico" da sociedade lacedemónia enraíza a duplicidade de interpretações do famoso "estilo lacónico"(22): embora decepcionante a um primeiro contacto, pela aparente pobreza de expressão (o discurso de Pausânias fala mesmo de uma argia psyches, "preguiça de alma", Symp. 182d), revela-se contudo, em momentos-chave, uma apurada arte de dizer, que apenas com um longo treino filosófico se alcança: daí - ainda segundo Sócrates... - o reconhecido apreço que os antigos sábios das mais variadas partes da Grécia (citam-se explicitamente os Sete Sábios) votaram às sociedades lacedemónia e cretense, internacionalizando o dito estilo lacónico através das máximas que deixaram no templo de Delfos e ficaram como legado comum de sabedoria para todos os Gregos (34.3a-b) ${ }^{(23)}$.

Descontando o inverosímil que sustenta o primado da sabedoria (melhor: da filosofia!) entre os Lacedemónios, o passo do Protágoras explicita claramente (tal como o Laques) a existência de uma faç̧ão pró-lacedemónia em Atenas, que à democracia vigente antepõe a prioridade da defesa do território e, com ela, a militarização da organização social, através de uma educação predominantemente orientada para a actividade física e guerreira. Essa facção - que, como se deduz, estaria também representada noutras póleis gregas - recebe mesmo um nome: os lakonizontes (343b), isto é, “os que procedem à maneira dos lacedemónios” por entenderem que nas suas instituições e hábitos de vida reside a razão de ser da sua superioridade.

(22) No mesmo sentido vai a distinção traçada em $L g$. I647-649b entre a philologia "amor à linguagem" e polylogia "abundância de linguagem" dos Atenienses face à brakhylogia dos lacónicos e cretenses: sobre este esboço de uma "etnografia do logos” vide H. Joly, La question des étrangers, p. 36.

(23) $\mathrm{O}$ texto do Protágoras é ambíguo, não respondendo claramente à questão de Delfos servir como ponto de encontro ou apenas de registo das ditas máximas. De acordo com a tradição afirmada por Heródoto, teria havido em Sardes um encontro promovido por Creso, o rei lídio que teria chamado Sólon à sua corte. Outro estrangeiro bárbaro - o faraó Âmasis - é referido como ligado aos Sete Sábios. Sobre a génese desta tradição e sua projecção na literatura posterior (em especial Plutarco) veja-se Delfim Leão, “Os ‘Sete Sábios' como agentes de formação”, Biblos, $2^{\mathrm{a}}$ série, 1 (2003) 23-41. 
Anote-se, no entanto, que essa faç̧ão, pelo menos nos diálogos platónicos, se manifesta num campo puramente teórico, jamais implicando atitudes concretamente hostis à democracia ou à política da cidade. O que está em causa, na apreciação relativa dos regimes de Atenas e Esparta, é qual deles poderá melhor servir os interesses da pólis e os valores comuns a todos os Gregos ${ }^{(24)}$. Por razões de eficácia, consideraremos globalmente a República e as Leis, à luz dos princípios legislativos e educativos de Esparta que nelas se reflectem.

$\mathrm{Na}$ estrita separação de domínios que há pouco aludimos (o da teoria e o da praxis) evolui o pensamento político de Platão. A simpatia pelas instituições cretenses e espartanas (que poderá ter sido herdada de Sócrates) não tem correlato em qualquer actuação política imediata, de que Platão praticamente abdicou, após a tentativa frustrada de estabelecer em Siracusa o princípio do "governante-filósofo", que a República desenvolve. Mas a investigação em torno do melhor modelo político-social de pólis jamais deixou de fazer parte dos seus projectos: um dos itens prioritários da fundação da Academia foi justamente preparar cidadãos que pudessem contribuir para aperfeiçoar os sistemas legislativos das diversas póleis e propor outros para as cidades que viessem a fundar-se - como, por várias vezes, veio a suceder ${ }^{(25)}$.

Com a perspectiva, a médio e longo prazo, de teorizar formas de constituição mais adequadas à defesa e ao bem-estar dos Estados, Platão corporiza uma preocupação tipicamente helénica que, não obstante divergências e limitações de região para região, corresponde desde cedo não apenas à necessidade de definir um estatuto de cidadania (isto é, formalizar a relação do indivíduo com o Estado) mas também de o englobar no sentimento de pertença a uma comunidade mais ampla, determinada por óbvias afinidades de religião, língua e de vivência social.

(24) A opção por um ou outro dos modelos revive no "século das luzes": "Esparta brilha como um clarão nas trevas imensas" proclama Robespierre (apud J. Ribeiro Ferreira, "Grécia e Roma na Revolução Francesa”, Revista de história e teoria das ideias 10 /1988/ 218) . Mais raros são os admiradores de Atenas, como Chénier. No que respeita em especial à adesão suscitada pela legislação e pela educação espartanas veja-se do mesmo autor, além do estudo citado, a comunicação “A presença da Grécia e de Roma na Revolução Francesa” in A recepção da Revolução Francesa em Portugal e no Brasil (Actas do Colóquio) (Porto, 1992) 75-96.

${ }^{(25)}$ Sobre este ponto, é instrutiva a leitura de P. Friedlaender, Plato. An Introduction (London, 1969) cap. III "Academy", esp. pp. 100-101. Outros aspectos sobre o funcionamento da Academia e a sua projecção na época (e para além dela) podem ver-se em M. Balthes, "Plato's School, the Academy", Hermanthena 155 (1993) 5-26. 
Embora nas suas cidades utópicas - a República e as Leis - Platão parta de pressupostos universais (ou assim tidos) na busca da eunomia, cujo alvo mais remoto é o bem-estar dos cidadãos que dela partilham, percebe-se que o contexto é o de uma cidade grega. Mesmo na República, intencionalmente alheada da polémica que divide os Gregos quanto à superioridade do regime de Esparta ou de Atenas, o perigo "de fora” que os Bárbaros representam, como o "de dentro", que são as guerras movidas por Estados helénicos entre si, confirmam o intencional estatuto de pólis grega, anunciado em 470e. Bem característico é o passo em que são proibidas as represálias dos vencedores sobre vencidos gregos, mas não sobre Bárbaros, numa directa crítica às práticas do tempo: "Com os bárbaros, devem proceder como actualmente os Helenos uns contra os outros.” (471b, cf. Menéxeno, 242d).

As Leis partem de um suporte teórico mais concreto e visam objectivos mais definidos - reformular as sociedades gregas existentes através do modelo de uma nova cidade. Sem renunciar de todo à perspectiva de um Estado ideal, a fundar desde os seus alicerces (739a, 807b), Platão contemporiza com a necessidade pragmática de trabalhar sobre a realidade existente - isto é, os regimes político-sociais de Esparta e de Atenas, cuja "candidatura" a organização-modelo da sociedade grega se põe desde as invasões persas.

Nesse empreendimento alternativo de construção da cidade ideal, as preferências legislativas de Platão vão explicitamente para o modelo espartano e cretense. A adesão a esse modelo, que influencia já vários tópicos concretos da República (como a educação comunitária de crianças e jovens, ou o modelo guerreiro de organização da pólis), deduz-se de uma extensa análise onde os aspectos positivos contrabalançam generosamente os negativos. Mas não se trata apenas de propor a excelência de um modelo, destacável no espaço e no tempo gregos, cuja eunomia parece satisfazer, de forma mais consequente, um princípio de isonomia arreigado em toda a teorização legislativa grega (e obviamente, reivindicado também pela democracia ateniense). A originalidade do livro III das Leis consiste em fazê-lo derivar da reformulação de um ideal pan-helénico, tentado já pelos Aqueus ao tempo da Guerra de Tróia ${ }^{(26)}$, mas que apenas mais tarde, com

(26) Deve-se provavelmente a Tucídides (1.3.3) a interpretação da Guerra de Tróia como a primeira grande aliança dos povos gregos, inserta na "Arquelogia" que antecede a narrativa histórica. Para uma análise desta "Arqueologia” (cujas reflexões passam em grande parte ao texto platónico), vide Ribeiro Ferreira, op.cit., pp. 444-446. 
os Dórios, adquire a consistência de um projecto (dianoia), consubstanciado na legislação de Creta e das cidades do Peloponeso.

Contra a expectativa - e provavelmente contra a verosimilhança histórica - Platão interpreta aqui, sob o signo da unidade étnica, os dados de uma tradição remota que falam da invasão do Peloponeso pelos Dórios: estes serão tão-só os Aqueus dissidentes ou expulsos após a Guerra de Tróia (por não serem aceites nas respectivas cidades) que, passado tempo, regressam sob o comando de Dorieu para dominar os que lá continuaram (682e) ${ }^{(27)}$. Do exílio, do contacto com povos bárbaros, potenciais invasores da Grécia, trazem ideias novas de governo para as cidades, no intuito não apenas de servirem mais eficazmente todos os cidadãos, segundo o princípio da isonomia, mas também de fomentarem a solidariedade entre elas, sempre que está em causa a defesa comum do território grego.

É significativo o passo $685 \mathrm{~b}-\mathrm{c}$, onde se exaltam as virtudes das leis "irmãs" (adelphoi) de Creta e dos principais Estados dóricos do Peloponeso (Argos, Messénia e Lacedemónia):

"No espírito dos homens de então, essas disposições não visavam apenas a defesa adequada do Peloponeso mas também a de todos os Gregos, caso algum povo bárbaro contra eles acometesse."

O elogio das instituições de Esparta tem, pois, a ver com o facto de este ter sido o único Estado dórico a manter fidelidade ao primitivo "projecto" (he tote dianoia) a que obedeceu toda a reformulação político-legislativa do Peloponeso, empreendida pelos Aqueus expulsos e regressados, agora conhecidos por Dórios: "se o antigo projecto tivesse vingado, concretizandose na união [dos Estados dóricos] ter-se-ia obtido uma força invencível na guerra" (686b).

As Leis apostam assim numa mitificação dos Dórios como símbolo por excelência da liberdade e da união helénica que, embora não excluindo Atenas (tal como no Menéxeno, a primeira a suster a invasão dos Bárbaros -

(27) As Leis contrariam a ideia corrente da invasão do Peloponeso por um povo grego, mas vindo de fora, que terá posto fim à civilização dos Aqueus. Esta fusão de Aqueus e Dórios (que tem mais a ver com o propósito de enfatizar uma união estrutural da nação grega a partir dos Dórios) conta curiosamente com o apoio de estudiosos de há poucas décadas, como Chadwick e Hooker, que a partir de dados linguísticos fornecidos pelas tabuinhas micénicas procuraram postular a coexistência espacial e temporal de Dórios e Micénios. Mas não é uma tese pacífica: vide Ribeiro Ferreira, Hélade e Helenos, esp. pp. 81-88 e bibliografia aí citada. 
698d-e), contraria o papel cimeiro que noutros excursos míticos dos diálogos lhe é outorgado (em especial no Timeu e no Crítias, obras cronologicamente próximas das Leis).

Será, no entanto, imprudente tirar deste facto ilações literais. Primeiro porque, no seu devir histórico, os Estados do Peloponeso (à excepção da Lacedemónia) não escapam à recriminação de terem, tal como Atenas, deixado desvirtuar os princípios da eunomia, estabelecidos pelos seus antepassados (692d); depois, porque estão em causa preceitos de convenção dramática que Platão jamais quebraria: seria inverosímil, no contexto do diálogo, vermos o Estrangeiro Ateniense (que nem sequer é Sócrates!) impor a primazia do mito dos "nascidos da terra" (autocthones) face aos dois interlocutores, claramente escolhidos como representantes de um ideal legislativo a que as Leis dão o seu beneplácito: Megilo, por Esparta e Clínias, por $\mathrm{Creta}^{(28)}$. É como hóspede deste último, e especificamente em Creta ("a Urland mítica da legislação grega", no dizer de Friedlaender ${ }^{(29)}$ ), que o Estrangeiro Ateniense delineia as traves-mestras da sua nova cidade; por isso, a glorificação dos "nascidos da terra" é aqui omitida em favor da dos Dórios da época pós-acaica, que são fundamentalmente o mesmo povo de quem partiu, embora por razões conjunturais, a primeira iniciativa de uma aliança de todos os Gregos.

Esta forma de homenagem ao povo dórico, e aos interlocutores que no diálogo o representam, só superficialmente deixa em segundo plano Atenas. Se não há dúvidas quanto à supremacia legislativa que para Platão (e para muitos outros Gregos) fez da Lacedemónia e de Creta modelos históricos de eunomia, não é menos certo que a reflexão sobre as suas virtualidades, e sobre os pontos em que é possível melhorá-los, cabe primacialmente a Atenas, à sua vocação especulativa e dialogante, que, quando longe de excessos populistas, obtém pelo consenso os resultados que a imposição, por

${ }^{(28)}$ O empenho na recriação dramática vai ao pormenor de fazer de Homero um poeta pouco menos que desconhecido em Creta. A citação dos versos de Od. IX112-115, pelo Estrangeiro Ateniense, merece de Clínias um comentário desconcertante: "Esse vosso poeta, acho eu, tem o dom de agradar! Dele correm também por aí entre nós outros versos deveras gentis, mas não muitos: é que nós, Cretenses, não somos muito dados a poesia estrangeira ...” A réplica do espartano Megilo não melhora a situação: "Bem ... isso, nós somos! Achamos mesmo que este bate aos pontos os poetas do género; mas o estilo de vida que ele representa é o iónico, não o espartano ...” (680c-d). Com esta nota "lacónica”, o Platão das Leis dá por arrumada a questão homérica, tão obcecadamente evocada nas páginas da República.

${ }^{(29)}$ Plato II, London, 1969, p. 338. 
si só, jamais alcança. Esse é reconhecidamente o mérito da cidade, a cujo papel de pioneira na união espiritual dos Gregos (como já no Menéxeno se frisara) ambos os interlocutores do diálogo prestam também homenagem no início das Leis. Megilo, proxenos ${ }^{(30)}$ de Atenas em Esparta, considera-a uma segunda pátria (642b) e é dos seus lábios que saem estas palavras, reminiscentes de outras que Platão pessoalmente faz ouvir na Carta VII, em defesa da sua cidade: "Quando os Atenienses são gente de bem, são-no ao mais alto ponto!"

\subsubsection{Atenas}

Tal como Sócrates integra sem conflitualidade a admiração pelas instituições espartanas e o seu radical apego a Atenas, também Platão permanece vinculado à sua cidade - embora, proventura, carregando uma desilusão mais funda, que se traduziu na completa abdicação da vida política (o que não aconteceu com Sócrates) ${ }^{(31)}$.

A evolução da obra platónica (tanto quanto dela nos podemos dar conta) traduz uma vivência de Atenas que de algum modo corresponde a um distanciamento progressivo por parte de Platão, bem como a uma gradual desfocagem do Sócrates histórico, cuja personalidade, fortemente sensível nas obras ditas socráticas, se concilia, nas da maturidade, com o papel de portavoz de Platão, para quase se reduzir ao de um mero ouvinte de estrangeiros ilustres, nos últimos diálogos (exceptuam-se, além das Leis, as recriações de diálogo aporético, representadas pelo Filebo e pelo Teeteto).

Não obstante as críticas que, directa ou indirectamente, marcam a posição de Platão no que respeita a Atenas, esta é indiscutivelmente, nas

${ }^{(30)}$ Os proxenoi correspondiam, grosso modo, aos cônsules actuais, com a diferença de que eram cargos desempenhados por naturais do Estado onde outros se faziam representar. Megilo, espartano, representa pois, na sua própria cidade, os interesses de Atenas. De salientar que, ao longo do séc. V a. C., proxenos passa a ser também um título honorífico concedido a estrangeiros: vide supra Delfim Leão no estudo publicado neste volume.

${ }^{(31)}$ Essa desilusão teve, muito em especial, a ver com o processo que culminou na condenação à morte de Sócrates, como explicitamente Platão refere na Carta VII, 325b-d. Regra geral não se põe hoje em dúvida a autenticidade das Cartas VII e VIII, sobretudo a VII, cujo conteúdo autobiográfico é apoiado, não só em concordâncias peculiares de estilo e de doutrina, mas também em ecos marcantes de uma experiência pessoal, dificilmente imitável. Para uma análise sistemática desse conteúdo autobiográfico vide Luc Brisson, "La lettre VII de Platon, une autobiographie?" in: Lectures de Platon (Paris, 2000) pp. 15-24. 
obras que integram a fase inicial e da maturidade, o palco das atenções, a cidade que assume a supremacia cívica e intelectual onde - pelo menos em teoria... - todas as ideias, por mais arrojadas que pareçam, podem debater-se. O esforço dos governantes por mobilizar todos os cidadãos nos grandes empreendimentos da pólis contam com esse instrumento cuja duplicidade de efeitos é diversas vezes salientado (e por isso mesmo recusado) por Platão: a arte da palavra ou retórica. Górgias, no diálogo homónimo, atribui-lhe uma das grandes realizações da cidade: a construção da grande muralha defensiva entre Atenas e o Pireu - obra de persuasão, não de técnicos mas de políticos e oradores eficientes, como Péricles e Temístocles (455d).

Independentemente da banalização e do mau uso que o excesso de liberdade da palavra foi impondo ás multidões, esse conceito de Atenas como um lugar privilegiado do "direito à palavra" passa do Sócrates histórico do Críton ao Górgias. Em 461e, após Sócrates fazer ver a Pólo que deve ser mais controlado no seu discurso, este pergunta se não tem o direito de falar como quer. A resposta de Sócrates não pode ser mais explícita:

"Estarias mesmo com pouca sorte, meu caro, se viesses a Atenas, o lugar da Grécia onde a palavra é mais livre, e fosses o único a ser privado desse privilégio!"

A isonomia, que os Lacedemónios praticam através de um regime de igualdade de educação e de vida, e da estreita subordinação dos interesses ou conviç̧ões pessoais ao Estado, é em Atenas afirmada pelo estímulo à livre expressão individual e ao contributo que a todos os cidadãos é pedido, nas grandes como nas pequenas tarefas que dizem respeito à pólis. Independentemente dos efeitos perversos que a democracia, entendida no seu sentido populista, possa levantar, esse é um dos créditos da cidade a que Sócrates se sentiu sempre vinculado. Nos diálogos ditos socráticos capta-se uma imagem forte de efervescência cívica e intelectual, permanentemente estimulada e aberta às novidades vindas de fora; e não por acaso, as conversas de Sócrates com os mais ilustres visitantes estrangeiros - sejam eles rapsodos ou sofistas - se saldam na inequívoca vitória do Mestre platónico: ela simboliza o poder de assimilação do imenso caudal de novas conquistas, na cultura e na ciência, a que a cidade é receptiva; e também essa última palavra que, em diálogo com os visitantes oriundos das mais diversas regiões da Grécia, lhe cabe. 


\subsubsection{A CidADE E OS MITOS DAS ORIGENS}

O Eutidemo e o mito de Íon

O mito do Íon representa a afinidade étnica e cultural dos grupos iónicos a que os Atenienses, como os Áticos em geral, pertencem. Essa afinidade é evocada claramente no passo 302b-d do Eutidemo. Dionisodoro pergunta a Sócrates se tem - isto é, venera - um Zeus ancestral (patroos). Sócrates nega; porém, perante o risco de "nem sequer ser ateniense" se não tiver deuses ancestrais, especifica que tal designação não é conhecida de nenhum dos Iónios, quer os de Atenas, quer os restantes emigrados: a designação de patroos "ancestral" cabe entre eles a Apolo, pai de Íon, de quem os Iónios (e, portanto, os Atenienses) descendem ${ }^{(32)}$.

Deixando à margem a questão de Zeus patroos (expressão que certamente era também utilizada em Atenas, mas não no sentido de "fundador da raça"), o passo tem interesse na medida em que acentua uma vivência banal do mito e a consciência de unidade de todos os Iónios, para quem a Ática é o local de origem.

A independência relativa que diversos grupos foram criando, com as vagas de emigração para as ilhas e para a Ásia Menor, justifica que, não obstante essa unidade étnica, se fossem implementando, ao longo do tempo, divergências não só linguísticas mas também culturais: o Banquete (182b), no que toca ao nomos relativo à pederastia, refere "grande número de regiões da Iónia" onde a vizinhança com os Bárbaros influencia negativamente padrões culturais e políticos (nomeadamente, em associação com o regime tirânico); também o Protágoras deixa a insinuação de que os povos nessa situação e não só os Iónios - em particular quando sujeitos ao domínio político dos Bárbaros - sofrem contaminações indesejáveis, não só na cultura como na língua.

É, portanto, a Atenas que reverte um padrão centralizador de mito, que privilegia a terra ateniense e a Ática, subalternizando de algum modo a relação com os povos iónicos emigrados. A época de Péricles documenta de forma extrema este cerrar de fileiras nacionalista, ao determinar que o estatuto de cidadania (ateniense) apenas possa ser concedido a filho de pai e mãe atenienses; para além da necessidade pragmática de impedir

${ }^{(32)}$ Para outros pormenores e bibliografia veja-se Monique del Canto, Platon. Euthydème (Paris, 1989) em nota ad loc., pp. 229-230 e Slobodan Dusanic, "Isocrates, the Chian Intelectuals and the Political Context of the Euthydemus”, JHS 119 (1999) esp. pp. 9-13, que integra o diálogo à luz das relações diplomáticas Quios/ Atenas por volta de 384 a.C.. 
o alargamento indefinido do número de cidadãos, pretendia-se com isto reforçar o espírito da eugeneia, "o bom nascimento", ${ }^{(33)}$ que, como se especificará, entra na estrutura do mito das origens porventura mais arreigado entre os Atenienses - o da autoctonia ${ }^{(34)}$.

Por razões de vária ordem, a exigência de ambos os progenitores serem atenienses foi revogada ainda no tempo de Péricles (o facto de ter casado com a iónia Aspásia e dela ter tido um filho não foi certamente alheio a isso), mas a questão estava a todo o tempo sujeita a reexame, particularmente em determinações oficiais: em 403 a.C., uma proposta de alargar o apoio do Estado aos órfãos da guerra civil contra a Tirania dos Trinta contempla unicamente filhos de pai e mãe atenienses. Sabe-se que o carácter arbitrário da proposta foi alvo de contestação num discurso judiciário atribuído a Lísias (Contra Teozotides), sendo também provável, como sugere Pamela Huby, que a crítica a tal lei (ou ao espírito que a ditou) tenha constituído um dos móbeis imediatos do Menéxeno: a parte final do discurso é um eloquente apelo às responsablidades da pólis quanto aos seus órfãos de guerra (248e-249c), numa linguagem que adverte claramente contra qualquer tipo de exclusão ${ }^{(35)}$.

(33) $\mathrm{O}$ número excessivo de cidadãos punha em causa a viabilidade da democracia directa, como sublinha C. Patterson em Pericles citizenship law of 451/450 b. C. (apud J. Ribeiro Ferreira, Hélade e Helenos, p. 99 n. 2). Mas que a essa preocupação de ordem pragmática se associa também o culto da eugeneia, mostra-o o dito corrente, atribuído a Sócrates, a propósito da" rusticidade" de Antístenes: "Vê-se logo que não é filho de pai e mãe atenienses ..."

${ }^{(34)}$ A época clássica associa ambos os mitos, fundindo-os numa sequência temporal: Íon, filho de Apolo e de Creúsa, é neto, por parte da mãe, do autóctone Erecteu. O testemunho literário paradigmático deste sincretismo é o Íon de Eurípides: veja-se a Introdução de F. Lourenço à tradução desta peça (Eurípides. Íon, Lisboa, 1993), pp. 24-26. Sobre as dificuldades que a junção de ambos os mitos levanta no entendimento da "cidadania", identificada com a autoctonia, cf. N. Loraux, Les enfants d'Athéna (Paris, 1984) esp. pp. 193-253 (cap. "Créuse autoctone”).

(25) Cf. "The Menexenus reconsidered" Phronesis 1957, esp. pp. 110-114. P. Huby aventa mesmo para a referida lei uma data próxima da composição do Menéxeno, que deverá situar-se pouco depois do ano da Paz de Antálcidas (386 a. C.): o discurso inclui já a referência a este evento histórico, num anacronismo várias vezes salientado (Sócrates morreu em 399 a.C.). Sem prejuízo da interpretação que a A. aí apresenta do diálogo, e que perfilhamos também, a leitura da obra fundamental de D. Nails (The People of Plato. A Prosopography of Plato and Others Socratics, Indianapolis, 2002, s.v. Theozotides, pp.281-282) veio chamar-nos a atenção para dados posteriormente surgidos: a proposta de Teozotides (seguramente, avô de um outro a que P. Huby pretendeu atribuí-la) foi de facto promulgada, constando de achados arqueológicos mais recentes, revelados em 1971 por Stroud; o facto de se referirem explicitamente os órfãos da guerra civil contra a Tirania dos Trinta (404 a.C.) confirma assim a data tradicional de 4.03 a.C. para a referida proposta. 
Ao atribuir o discurso a Aspásia, Platão terá visado assim contrapor à glorificação exclusiva de Atenas a lembrança de um passado comum e de uma solidariedade mais vasta entre todos os Iónios que o mito de Íon recorda, realçando afinidades específicas de língua e de tradições religiosas, que os distinguem dos restantes Gregos ${ }^{(36)}$.

\section{O Menéxeno e o mito da autoctonia}

Em época constante de lutas e dissensões entre Gregos, protagonizadas em especial por Atenas e Esparta, as cerimónias fúnebres em honra dos combatentes mortos e o elogio oficial que as acompanhavam eram momentos culminantes de reflexão sobre a cidade, os seus valores e os seus heróis. O prólogo do Menéxeno dá conta do espírito de exaltação nacionalista que a retórica oficial visava, a ponto de o próprio Sócrates se imaginar, por alguns dias, a habitar "as Ilhas dos Bem-Aventurados" (235c). Com o desconto irónico que haverá que dar-lhe, a imagem atesta a eficácia de um estilo oficial (ou "discurso de Estado", como lhe chama I. Lowenclau ${ }^{(37)}$ ) e onde o elogio dos heróis se mistura ao da cidade. É através do mito da autoctonia, ou seja, dos "nascidos da terra", que a pólis reafirma a sua vocação específica, o seu destino e ideais, determinados à partida pelo sentido de pertença aos seus deuses (Atenas e Hefesto) e à própria terra. ${ }^{(38)}$ Como pertinentemente realça N. Loriaux, o mito das origens é o que melhor se presta a interpretar a identidade de uma pólis ${ }^{(39)}$.

"Mãe" e "ama” (meter, trophos), a terra "cara aos deuses" (theophiles) é a condição primeira de eugeneia, "o bom nascimento" dos seus habitantes, a que se associam os princípios consagrados de liberdade (eleutheria) e

(36) No nosso estudo "Retórica filosófica feminina em Platão: Aspásia e Diotima" in Retórica, Política e Ideología: Desde la Antiguidad hasta nuestros días (Salamanca, 1998) pp. 223-228, pode ver-se um desenvolvimento dessa perspectiva, esp. pp. 224-226.

(37) Der platonische Menexenos, Stuttgart, 1962, p. 39. A visão de total seriedade que o A. aí argumenta opõe-se à interpretação paródica mais corrente: cf. e.g. Nicole Loraux, "Socrate, le contrepoison de l'oraison funèbre", AC43 (1974) 172-211 e L. Coventry, "Philosophy and Rhetoric in the Menexenus, JHS 109 (1989) 1-15.

(38) Cf. Crátilo, 406d: Hermógenes incita Sócrates a prosseguir nas etimologias dos nomes dos deuses desta forma: " Claro que não vais esquecer Atena, Sócrates, na tua qualidade de Ateniense, nem tão-pouco Hefesto e Ares ...”

(39) Vide Les enfants d'Athéna (1981), esp. p.36. O apego platónico ao mito da autoctonia é visível em outros contextos, mesmo quando encarado como "nobre mentira" - Rep. III, 414.c-e. Cf. $L g$. II 663e e Pol. 269b. H. Joly apresenta uma sugestiva síntese destas ocorrências, de origens míticas diversas: vide Études platoniciennes. La question des étrangers (Paris, 1992) pp. 18-20. 
de igualdade (isonomia) entre todos. Sem entrar na análise de inovações específicas que Platão opera relativamente a outros modelos de "discurso de Estado", como o de Péricles em Tucídides, ou de oradores consagrados do séc. IV a.C. como Isócrates e Lísias ${ }^{(40)}$, é patente a procura de instilar no mito ideais arreigados da mentalidade ateniense, que têm a ver com a sua história e as suas vivências de cidadania.

É assim que a isonomia, miticamente explicada pela isogonia ou "igualdade de nascimento" dos seus autóctones, encontra concretização plena no regime democrático (demokratia), cuja excelência Atenas antepõe a todos os outros (num volte-face platónico, a Aspásia do Menéxeno converte-o num aristokratia "governo dos melhores" com assentimento do povo):

“... é, na maior parte, o povo que detém o poder na cidade: é ele que atribui os cargos e a competência de mandar aos que se lhe afiguraram os melhores; ninguém é preterido por razões de doença, pobreza ou obscuridade do seu nascimento - como também ninguém é agraciado pelas razões contrárias, como nas demais cidades" (238d).

Subjacente a estes valores está um conceito de humanidade, ele também "autóctone", que marca a primazia dos Atenienses sobre os outros povos e Estados:

"Numa época recuada em que a terra inteira [apenas] produzia e fazia crescer toda a espécie de seres vivos - animais e plantas - a nossa abstinha-se de dar vida às feras e aos animais selvagens, dando de si uma imagem sem mancha. Foi ela que gerou o homem, superior a todos os demais seres pela inteligência e por ser o único a venerar a justiça e os deuses" (237d).

Esse conceito de humanidade não se encerra numa "autoctonia" isolada e restrita a Atenas; parte integrante dela é a vocação solidária para repartir, com os outros povos gregos, as dádivas de que foi abundantemente provida: o trigo, a cevada e a oliveira (238a-b). O mito prenuncia, pois, nos começos da pólis, o sentido de identidade e o de partilha, que acompanha idealmente a história, não só de Atenas como de toda a Grécia. A generosidade com que antes a cidade "cara aos deuses" (theophiles) repartia os produtos da

${ }^{(40)}$ São sobretudo visíveis as concordâncias com o Elogio Fúnebre de Lísias: veja-se em J. Ribeiro Ferreira, Hélade e Helenos, pp.471-476, a inventariação de tópicos aflorados em ambos os discursos, que coincidem numa linha de interpretação histórica tipificada. 
terra é a mesma (na óptica do Menéxeno e dos demais "discursos de Estado") que a faz promover valores de isonomia e de liberdade individual e cívica, oriundos de um conceito de humanidade mais puro (katharos, 237d).

Com as invasões persas, a vocação mítica de Atenas projecta-se na história como garante não só do seu povo, mas dos demais povos gregos. Não por acaso se salienta a circunstância de ter sido Atenas a única pólis a afrontar os Persas, na primeira invasão (derrotando-os em Maratona) e de apenas dez anos mais tarde, por ocasião da segunda, ter sido secundada pelos Lacedemónios. Ao longo do século de Péricles, após os precários anos de coesão nacional contra o inimigo comum (os Bárbaros), é esse papel cimeiro que Atenas invoca para dar legitimidade às suas pretensões a uma hegemonia, e à parte activa que assume nas guerras que assolam as póleis desavindas.

O perigo, simbolizado nos Bárbaros, de aniquilamento da vivência grega da liberdade acorda, para além do sentimento da pátria individual, que em Atenas se traduz no mito da autoctonia, o de uma pátria colectiva, determinada por uma unidade de raça e de língua mais ampla (como o Crátilo salienta), que abrange todos os Helenos e confere aos diversos grupos o estatuto de "irmãos" (homophylon, Menéxeno 242d, cf. adelphoi, na República) $)^{(41)}$.

Não admira, assim, que críticos literários antigos, como Dionísio de Halicarnasso e Hermógenes, tenham visto no Menéxeno a lídima expressão de uma homenagem que Platão aí consagra à sua cidade ${ }^{(42)}$ : o decorrer dos anos foi diluindo intencionais desníveis com a realidade histórica e social evocada no discurso, desvalorizando os factores marcadamente paródicos da sua introdução. Como Loraux expressivamente assinala, a Atenas do Menéxeno "posa para a Eternidade, /.../ tão incapaz de se mover como o Ser de Parménides". ${ }^{(43)}$ Lido num só registo, e na idealização que a distância temporal permitie, o louvor a Atenas identifica-se ao seu papel

(41) Outras repercussões literárias e artísticas das invasões persas, que demonstram o salto qualitativo trazido por estas na evolução de uma consciência e identidade nacional são analisadas em J. Ribeiro Ferreira, Hélade e Helenos, pp. 221-232.

${ }^{(42)}$ Cf. P. Huby, “The Menexenus reconsidered”, pp. 104-106, e a Introdução de Méridier à edição bilingue de Les Belles Lettres: Platon, Oeuvre complète. Ion, Ménexène. Euthydème (tome V), Paris, 4/1964, p. 76. Nas páginas 60-64 desta Introdução pode ver-se também uma resenha pormenorizada de omissões e mesmo desvios à realidade histórica, que prejudicariam a intenção panegírica do discurso.

(43) Na p. 181 do artigo citado supra, na n.32. 
pioneiro na conscencialização e na defesa dos valores civilizacionais que, independentemente de divergências, congregam no mesmo espírito de "nação" todos os povos gregos.

Se os contemporâneos poderiam facilmente detectar brechas na seriedade pretendida desse louvor, as gerações futuras leram-no tão-só à luz desse apelo vivo, que no colorido da evocação mitológica e da emotividade retórica trazia novo alento à era de dominação macedónica que se seguiu. Segundo informa de Cícero, ainda no seu tempo a recitação do discurso de Aspásia integrava obrigatorimente as festividades do dia anual consegrado à Atenas ${ }^{(44)}$.

\subsection{Atenas e o binómio Grego/ Bárbaro}

\subsubsection{INFLUÊNCIAS BÁRBARAS PRIMITIVAS}

Não surgindo nos diálogos como personagens ou como figurantes, salvo as excepções atrás apontadas do Ménon e do Lísis, os Bárbaros constituem, no conjunto, os povos não gregos, circunstância que pode associar-se ou não a um juízo negativo. Do mesmo modo que to barbarikon exprime no Crátilo o que se não compreende, em função da língua, também num contexto propriamente étnico ou cultural a ideia de barbaros se alia à de "estranho" (allotrion), por vezes sem mais conotações ${ }^{(45)}$.

Parece ser esse o caso do Fédon 78a, onde Sócrates aventa a hipótese de Símias e Cebes encontrarem o "virtuoso" capaz de ministrar o encantamento apropriado a curar a alma quer na Grécia, quer nas nações bárbaras, "que são numerosas” (polla). Esta capacidade de cura, espiritual ou física (ou ambas), é aliás um dos domínios em que o Sócrates platónico aceita uma possível superioridade dos Bárbaros - talvez não indistintamente e apenas dos Trácios, cuja tradição xamanística aporta à Grécia a partir dos secs.VIIVI a.C., projectando-se em seitas religiosas e filosóficas (ou para-filosóficas) como o Orfismo e o Pitagorismo ${ }^{(46)}$.

(44) Orator, xliv, 151 (apud P. Huby,” The Menexenus reconsidered”, p. 105).

${ }^{(45)}$ Consoante ficou demonstrado nos trabalhos que antecedem estas páginas.

(46) Quanto à problemática distinção entre Orfismo e Pitagorismo, vide M. H. Rocha Pereira, estudos de História da Cultura Clássica I. Cultura Grega, Lisboa, 2003, pp. 314-317 e bibliografia citada (daqui em diante: Cultura Grega). A projecção da cultura xamanística na Grécia e a sua 
No Cármides 157a-c Sócrates, recém-chegado de Potideia (nas vizinhanças da Trácia), propõe-se curar as dores de cabeça do interlocutor que dá o nome ao diálogo com um encantamento ou mezinha (epoide) que lhe fora ensinada pelos médicos trácios, discípulos de Zalmóxis. E, no conjunto, a noção de êxtase ou delírio divino (enthousiasmos, "ter o deus em si") - particularmente na ligação a rituais religiosos como os dionisíacos, de origem provavelmente asiática ${ }^{(47)}$ - preenche parte substancial da imagética platónica, não só no que concerne à adivinhação e aos ritos purificadores, mas também à poesia e ao ao amor, identificável, na sua forma mais elevada, com a filosofia.

Sintetizando referências anteriores, o Fedro (244a-245c) associa explicitamente estas quatro formas de "loucura divina" (theia mania) - conceito, como se sabe, irrelevante em Homero, que jamais associa as numerosas referências do "poeta inspirado" (entheos) à ideia de "estar for a de si" (ekphron) que as épocas posteriores desenvolverão ${ }^{(48)}$.

Bem significativo desse contraste é o passo 533c-536d do Íon, onde Sócrates define a criação poética, bem como o envolvimento nela de rapsodos e ouvintes, como uma cadeia de possessão divina (katekhesthai, 534a), que tem a sua origem nas Musas. "Ter o deus em si" ou enthousiazesthai (533d)

influência em ambas as doutrinas é uma das contribuições centrais de E.R. Dodds em Os Gregos e o Irracional (trad. port.: Lisboa, Gradiva, 1988, pp. 149-173). De notar, contudo, no tocante ao Orfismo, que a descoberta em 1962 do papiro de derveni, datado do séc. IV a. C., a que se têm seguido outros achados significativos em vasos, inscrições e papiros, invalidam as suspeitas de uma mistificação tardia da literatura órfica, levantadas em especial por Wilamowitz e em que Dodds apoia parte da sua análise (ibidem, pp. 162-165). O teor desses testemunhos aponta para a ligação, etabelecida já por Heródoto (2.123), entre Orfeu e o egipto, donde aquele teria importado o essencial da doutrina e dos rituais órficos referentes ao Além - tese recentemente retomada por W. Burkert, que a alicerça num minucioso e sugestivoconfronto entre a literatura órfica mais antiga (documentada nos achados das últimas décadas, e informações várias recolhidas em textos egípcios: vide "Orpheus und Aegypten" in Die Griechen und Orient. Von Homer zu bis Magiem (Muenchen, 2004).

${ }^{(47)}$ Sobre esta questão veja-se W. Burkert, A religião grega na época clássica e arcaica (Lisboa, 1993), trad. do al., pp. 318-328.

${ }^{(48)}$ Para o conceito de poesia homérica (que domina toda a época arcaica) vide M.H. Rocha Pereira, "O conceito de poesia na Grécia arcaica”, Humanitas 13-14 (1962) 336-357. É sugestivo o contraste que Abraham Avni estabelece entre a inspiração do aedo homérico e o poeta do Íon, cujo tipo de inspiração tem sido comparado ao dos profetas do Antigo Testamento: vide "Inspiration in Plato and the Hebrews Prophets", Comparative Literature 20 n. ${ }^{\circ}$ (1968) 55-63. O autor rejeita esse paralelo pela total passividade e perda da noção de si mesmo que o êxtase poético implica no Íon, sublinhando, pelo contrário, a pertinência da aproximação ao aedo homérico. 
não é apenas privilégio dos iniciados mas também dos poetas autênticos que as Musas elegem como seus intérpretes - a todos os títulos, comparáveis às Bacantes ou aos sacerdotes da deusa frígia Cibele (os Coribantes). Além dos poetas épicos,

“... tal como os Coribantes não dançam senão quando estão fora de si, também os poetas líricos não estão em si quando compõem esses belos poemas; mas, logo que entram na harmonia e no ritmo, são transformados e possuídos como as Bacantes ..."(49) (533e-534a).

Outro dos passos famosos, que remete para o valor catártico de rituais orgiásticos, acompanhados de uma música evocativa nos ritmos e nas melodias, é o do Banquete 215b-e, onde Alcibíades compara os discursos de Sócrates às melodias do mítico Mársias; os efeitos de agitação física e psíquica que provocam, devidamente sublinhados pela ideia de "possessão divina” presente no uso katechesthai ( 215c), explicitam-se na alusão repetida aos Coribantes ${ }^{(50)}$ :

"Sempre que o ouço, o coração bate-me com mais força ainda que o dos Coribantes, as lágrimas caem-me sob o efeito das suas palavras e esta emoção, vejo que não sou o único a sofrê-la mas inúmeras pessoas também.”(215e).

A interpenetração de culturas, no que toca a divindades e aos seus cultos, manifesta-se aliás, também ao âmbito da terminologia musical que, dos cinco principais modos, contém dois indubitavelmente evocativos de uma origem asiática: o frígio e o lídio, a par do dórico, do iónico e do eólico ${ }^{(51)}$. Não é claro se estes modos seriam musicalmente entendidos como associados a características étnicas: a República, pela voz autorizada de Glauco, sanciona, quer o modo dórico quer o frígio, como adaptados à educação dos guardiãos, excluindo os restantes (399a); se tivermos em conta o critério exclusivamente ético e educativo da opção - cingida, portanto,

${ }^{(49)}$ Trad. de Victor Jaboullie, Platão. Íon (Lisboa, 1992).

${ }^{(50)}$ Para uma perspectiva global dos rituais e da linguagem que se lhe associa, vide Dodds, Os Gregos e o irracional, cap. III, particularmente pp. 93-95, no que toca à poesia. Sublinhe-se que nas Leis (315c-d) tàis rituais são excluídos da cidade pelo seu carácter alienatório e estranho aos Gregos - ou, pelo menos, aos cidadãos que ela pretende formar.

${ }^{(51)}$ Outros aspectos complementares sobre os modos gregos são referidos por M.H. Rocha Pereira em Culturá Grega no capítulo dedicado à música grega (pp. 641-656). 
ao efeito "bom" ou "mau" das produções musicais criadas nesse modos - subentende-se que, em princípio, já nada associa o carácter musical dos modos às designações étnicas pelas quais são conhecidos.

É, no entanto, possível que os nomes evoquem por si algum significado (ético e cultural) quando, no Laques, o general que comandou com Sócrates a retirada de Délion alude ao modo dórico como o único em que é possível promover o acordo entre "as palavras e os actos". Mais: o modo dórico constitui "a única harmonia grega" (188d). Neste caso de purismo rácico estreme, estará subjacente a ideia de que Eólios e Iónios - os grupos étnicos mais afectos à colonização da Ásia menor - teriam sofrido contaminações indesejáveis dos estilos de música (e de vida) aí existentes, à semelhança do que o Protágoras e o Crátilo assinalam para a linguagem.

\subsubsection{Apuramento Dicotomia GRego/ bárbaro}

À parte o substrato genérico destas e doutras influências primitivas, cuja integração Nietzsche privilegiou como marca maior da genialidade helénica e das suas realizações em $O$ nascimento da tragédi $a^{(52)}$, a imagem dos Bárbaros rastreável nos diálogos platónicos da $1^{\underline{a}}$ e da $2^{\underline{a}}$ fases é dominada pela dicotomia grego/ bárbaro que o séc.V a.C. desenvolve em diversas facetas. Mesmo na procura de princípios universais, válidos para todos os homens (o que é uma constante dos diálogos), a necessidade de recurso a fórmulas como "quer entre os Gregos quer entre os Bárbaros" trai a presença mais ou menos consciente dessa dicotomia.

(52) $O$ nascimento da tragédia alicerça-se na dualidade representada por Apolo (de matriz helénica), que simboliza a luz e a racionalidade, e Dióniso (tomado aí como de matriz asiática), o deus das forças irracionais e dos ritos orgiásticos, a quem se associa a capacidade de projectar a vida até aos níveis extremos da destruição e autodestruição.

À parte o facto de Diónisos figurar já nas tabuinhas micénicas, como resulta da descoberta do linear B (cf. M.H. Rocha Pereira Cultura grega, p. 318) o esquematismo da tese de Nietzsche, neste ponto apoiado por Rohde, não se sustém cientificamente: vide E.R. Dodds, op.cit., pp. 80-81.

A dualidade nietzschiana é retomada pelo escritor cubano Somoza, num recente (e bem documentado) romance, $A$ caverna das ideias, onde se dá ênfase ao conflito aberto entre os ideais da Cidade platónica, representada pela Academia, e a irracionalidade do instinto humano, consubstanciado e potencializado nos rituais báquicos, que têm como cenário o bairro mal-afamado (à altura ...) do Liceu, em Atenas: cf. Minos 315c. 
Platão, pelas suas personagens, manifesta-a obviamente, tanto no debate ideológico como em alusões dispersas que, por via de contactos directos ou literários (em especial Heródoto), entraram no repertório de conhecimentos comuns. Se algumas delas são elogiosas, como a medecina trácia no Cármides ou a arte de retirada que o Laques (191a) atribui aos Citas (povo da zona norte da Europa que confina com a Ásia), outras frisam o desdém por um estilo de vida inferior, de que estão ausentes quaisquer preocupações educativas: os Cários (povo do Sudoeste da Ásia Menor) constituem, a este respeito, um lugar comum, a deduzir do Laques (187b) e, principalmente, do Eutidemo 285c, onde Sócrates se oferece desportivamente como "cário"(leia-se: "cobaia”) aos dois irmãos sofistas, para que nele testem a eficácia das suas experiências educativas - eventualmente, tão perigosas como as de Medeia da Cólquida... O mesmo diálogo refere ainda, no que toca aos Citas, o costume de utilizarem os crânios de inimigos como taças (299e), costume cuja barbárie os Gregos, educados na melhor tradição homérica de respeito pelo inimigo morto, não podiam deixar de repudiar.

Esse primarismo acorda-se, de resto, com um conceito genérico sobre os povos bárbaros da Europa, possivelmente extensivo aos trácios (recorde-se a lenda do esquartejamento de Orfeu às mãos das mulheres trácias) e aos "semi-gregos" macedónios que com eles convizinhavam - o que se deduz da referência do Górgias às atrocidades cometidas por Arquelau, no intuito de se apoderar do reino macedónio (470d-471d).

Os Bárbaros da Europa não constituíam, contudo, uma frente política ou militar que surgisse como ameaça à Grécia; pelo contrário, o seu estilo de vida algo tribal (há mesmo referência ao nomadismo dos Citas num dos diálogos apócrifos - Eríxias, 400e) fazia, deles também, alvo fácil das ambições de conquista do Império Persa. No Menéxeno está subjacente a ideia de que o papel de guardiãos da liberdade (eleutheria) que os Atenienses assumiram no decurso das invasões de Dario e, mais tarde, de Xerxes não apenas salvou a Hélade da tirania asiática mas também os restantes povos bárbaros da Europa (e ainda o Egipto e a Líbia: cf. 239d-e).

O discurso de Aspásia, embora tipificado numa moldura de "linguagem oficial”, acentua com razoável precisão que, para os Gregos, a defesa dos seus valores civilizacionais integra também o direito que outros povos não gregos têm a uma autonomia política e à salvaguarda das suas normas e modos de vida. 


\subsubsection{O GRANDE-ReI}

À medida que o confronto grego/ bárbaro, de base linguística e étnica, se vai precisando como barreira de natureza política e cultural, que opõe em especial os Gregos - maioritariamente no continente europeu - aos Persas do continente asiático (e povos a eles sujeitos), a figura do Grande-Rei emerge como ponto de referência, não só da vida política mas também de valores e ideais humanos, presentes na mentalidade grega.

Esse confronto pauta-se pela moralidade explícita que Heródoto veicula na narrativa do encontro entre Sólon e Creso ( I, 30-32): será a abundância de tesouros, o prestígio conjunto do poder e da riqueza, garantia suficiente da eudaimonia «felicidade» a que todo o homem aspira? A sabedoria grega do meden agan, pela voz de Sólon, responde negativamente. O que não significa que o bem-estar material e o reconhecimento social não preencham, pelo menos aos olhos do homem comum (mesmo grego ...), um requisito importante dessa procura ${ }^{(53)}$.

Por outro lado, as relações a nível diplomático que se foram institucionalizando entre Gregos e Bárbaros, após as invasões, acabaram por conferir um estatuto especial ao Grande-Rei, que se reflecte na consideração de que gozam aqueles que, por via de funções diplomáticas ou outras, se tornam seus hóspedes - como vimos atrás, a propósito de Pirilampo, tio de Cármides. ${ }^{(54)}$

Independentemente de sentimentos mais ou menos hostis que os Bárbaros (e entendemos aqui os Bárbaros invasores das primeiras décadas do séc.V a.C.) pudessem suscitar, o Grande-Rei instala-se no quotidiano ateniense com a aura mítica que o prestígio de um poder e de uma riqueza ilimitados revestem sempre na imaginação popular. Se, de um ponto de vista político (e ético), as realizações expansionais de Ciro, Dario e Xerxes são fruto de uma prepotência lesiva da liberdade e dos direitos dos outros povos, como o Górgias e sobretudo o Menéxeno (239d-241e) evidenciam, a imagem em si do Grande-Rei despoja-se de circunstancialismos políticos

(53) A história tornou-se, para os Gregos posteriores, um símbolo do contraste entre a mentalidade bárbara e a grega: cf. Delfim Leão "Sólon e Creso: fases da evolução de um paradigma", Humanitas 52 (2000), pp. 27-52 - embora, numa perspectiva mais consentânea com os diálogos platónicos, se não exclua a possibilidade de visar "as limitações de determinado universo axiológico próprio também da sociedade grega” (p. 47). A visão do 'Outro’ em Heródoto foi tratada por C. Soares neste volume.

(54) Vide supra, p. 267. 
e históricos para se configurar como um contraponto do meden agan, uma forma "outra" de ver o mundo e de aferir os valores que sustentam a felicidade humana.

É geralmente neste contexto que a figura do Grande-Rei é evocada nos diálogos platónicos, quase sempre com o epíteto megas "grande" - se exceptuarmos a eliminação sistemática do Menéxeno, que poderá explicarse pontualmente pela recusa de confirmar o estatuto de "grande» para o Rei que objectivamente procurou reduzir os Gregos à escravidão ou ao aniquilamento $^{(55)}$.

Uma referência de tipo comum é a do Lisis, quando, no decorrer da conversa com Menéxeno, Sócrates sobrepõe a paixão de fazer amigos (erotikos, $211 \mathrm{e}$ ) a outros bens e, explicitamente, às riquezas de Dario. Também no Ménon, como vimos atrás, a noção de arete «mérito» ou "virtude", que Ménon propõe, associada à riqueza e aos cargos e honrarias da cidade, merece de Sócrates o reparo de que o interlocutor fala na qualidade de «hóspede hereditário do Grande-Rei».

Assim, é na mesma ordem de ideias que vemos, no Eutidemo, a sabedoria (sophia) integrar o conjunto de valores que Sócrates - e podemos nele subentender os Gregos em geral - antepõe a todas as tradicionais vantagens do Grande-Rei: ao ouvir os dois irmãos assegurarem a sua recente capacidade para transmitir virtude e sabedoria, Sócrates comenta ironicamente: «Se assim é, felicito-vos por essa aquisição, muito mais que ao Grande-Rei pelo seu poder» (274a).

E não restam dúvidas do apreço «bárbaro» pelo ouro, que a referência subentende, quando Ctesipo faz notar, quase no fim (299e), que entre os Citas os mais realizados e felizes (ou ricos: eudaimonestator) são os que têm ouro, em boa quantidade, nos «seus» crânios ...(56) Não sendo directamente referida ao Grande-Rei, esta visão brutal (e, naturalmente, satírica) da felicidade proporcionada pelo ouro não foge à questão comum que, num plano mais elevado, o filósofo do Teeteto recusará indagar: «a de saber se o Grande-Rei será feliz com os seus lingotes de ouro ...» (175c).

${ }^{(55)}$ Nas Leis 695c Platão faz explicitamente o reparo de que, depois de Dario, nenhum soberano persa voltou a merecer tal qualificativo.

(56) Trocadilho: os "crânios" referidos aí, como se se tratasse das cabeças dos seus possuidores, são na realidade os dos inimigos vencidos e mortos, de que o guerreiros citas se apoderavam como despojos, fazendo deles taças para uso pessoal. Os mais ricos, de acordo com a informação de Heródoto (IV, 65) forravam o seu interior com ouro. Veja-se C. Soares, A morte em Heródoto (Lisboa, 2003). 
Nem tudo, no entanto, parece relegável na imagem estereotipada dos Bárbaros que Atenas, ao tempo de Sócrates e de Platão, veicula nos diálogos. Viu-se no Crátilo como, no plano da linguagem, tanto as línguas bárbaras como o grego (nas suas variantes «xénicas»), se equiparam, em termos de funcionalidade. A evocação do tear que, embora de materiais diversos, de acordo com o uso dos diferentes povos, cumpre sempre a mesma função, realça bem que, no tocante à techne, a distinção entre Gregos e Bárbaros não faz sentido, observação que o Lísis encaminha para outro domínio predilecto das conversas socráticas - o da educação.

Ao insistir que os pais de Lísis, por muito que o amem, só o deixarão administrar a casa quando estiver preparado para tal, Sócrates apela para a autoridade do Grande-Rei. Não é ao filho primogénito (apesar das suas prerrogativas) que confiará a missão de confeccionar um cozinhado e sim a quem dê garantias de o saber fazer, seja ele grego ou bárbaro. A ilustração, na aparência extravagante, é suficientemente justificada por Sócrates (210a-b):

«... nas coisas em que nos tornamos conhecedores, todos confiam em nós, Gregos e Bárbaros, homens e mulheres» ${ }^{(57)}$

A confiança em quem é reconhecidamente especialista num determinado domínio ultrapassa assim fronteiras de raça ou de distinção de sexos: é um princípio universal a que nem o Grande-Rei se exime, mesmo contra os desejos dos seu primogénito.

De resto, o cuidado que a educação do príncipe herdeiro merecia entre os Persas é, nos diálogos - como talvez em círculos atenienses -, um factor em apreço. A Ciropedia de Xenofonte, que descreve em traços largamente romanescos a educação de Ciro-o-Antigo, testemunha essa faceta a que culturalmente os Gregos podiam ser mais sensíveis (para o que não deixariam de contribuir pressupostos educativos da sociendade lacedemónia, e até de influência socrática, que a obra parece documentar, à margem da objectividade histórica $\left.{ }^{(58)}\right)$.

Na sequência talvez da Ciropedia, o Alcibiades I, atribuído a Platão ${ }^{(59)}$, apresenta uma minuciosa descrição de etapas que, desde o nascimento,

${ }^{(57)}$ Tradução de Francisco Oliveira.

(58) Vide infra, p.

${ }^{(59)}$ Só no séc.XIX a autenticidade do diálogo (incluído como genuíno no corpus platonicum) foi posta em causa. Para uma história da problemática, até 1964, vide P. Friedlaender (defensor 
marcam a educação do príncipe herdeiro; frisa-se, em particular, a circunstância de os seus tutores serem gente escolhida e responsável para quem, por sua vez, a função de acompanhar o crescimento físico, espiritual e social do futuro rei é fonte de prestígio e de honras (121d-e). Por contraste, Alcibíades, embora pupilo de Péricles e oriundo de uma das mais ilustres famílias atenienses, apenas teve como pedagogo um velho escravo trácio, de quem não se poderiam esperar capacidades necessárias para desenvolver em Alcibíades os dons inatos para a governação. Ao comprazer, neste ponto, com a excessiva auto-estima de que o seu interlocutor dá mostras, Sócrates frisa também ironicamente a sua desvantagem, ao querer apresentar-se como rival do Grande-Rei (123c).

O confronto é artifical, na medida em que um dos aspectos vivamente rejeitados pelos Gregos era a desigualdade gritante e arbitrária entre condições dadas ao rei e aos seus súbditos, na generalidade das sociedades bárbaras - aqui, representadas pelos Persas. E, naturalmente, a educação de Alcibíades, como a de todos os seus compatriotas nobres, estava longe de confinar-se ao acompanhamento de um escravo pedagogo. Platão, ou o autor do Alcibíades I, pretendeu sobretudo salientar, a partir do exemplo do Grande-Rei, a falha que o Estado democrático de Atenas ostentava: apesar de um nível cultural inegavelmente superior, os seus responsáveis não souberam prever uma preparação específica de futuros governantes. É essa lacuna que, paralelamente à Academia, Platão procurou preencher, em tempos diferentes (e por formas diferentes) na República e nas Leis, com base no ideal do filósofo-rei ${ }^{(60)}$.

\subsubsection{NOMOS / PHYSIS NO BINÓMIO GREGO / BÁRBARO}

O Menéxeno reproduz, como vimos, a leitura tradicional que o séc.V grego fez da sua história recente, ao situar nas invasões persas o momento

convicto da sua autenticidade, pelo menos nas décadas vinte e trinta) Plato I (trad. inglesa) (London, 1964) pp. 231-232 e n.1, pp. 348-349. Pessoalmente, sinto também a autoria platónica do diálogo como problemática - o que não interfere no contributo que traz para este tópico.

${ }^{\left({ }^{60)}\right.}$ É por demais ilustrativo e citado o passo da Carta VII onde Platão, após reconhecer que "todos os Estados actuais são mal governados, já que a sua legislação enferma de incuráveis males" (326a), justifica a sua consagração plena à filosofia: "os males não acabarão para as raças dos humanos enquanto uma raça de puros e autênticos filósofos não assumir os poderes políticos ou enquanto os que detêm esses poderes não se entregarem, por uma espécie de mercê divina, à filosofia." (326a-b). 
decisivo de conscencialização de uma unidade helénica. É no rescaldo da vitória sobre os invasores que a dicotomia grego/ bárbaro passa a centrar-se em valores existenciais e civilizacionais, que consagram a primazia de um “modo de ser helénico" face aos Bárbaros - norteado, antes de mais, pelo ideal de liberdade (eleutheria) e de igualdade perante a lei (isonomia).

Até que ponto estes valores (apesar dos diferentes registos interpretativos, que opõem o mundo dórico ao mundo iónico $\left.{ }^{(61)}\right)$ se foram assumindo como dado, por assim dizer, "racial”, proclamando uma superioridade do homem grego, assente na physis "natureza", deduz-se de esforços vários de pensadores do séc.V a.C., como Tucídides, por remeter para aspectos acidentais de meio (geográfico, climático), ou de níveis diferentes de civilização, certas divergências mais notórias entre Gregos e Bárbaros.

Nessa linha, o Crátilo platónico assume sem preconceitos um estádio remoto, "arqueológico" em que a oposição grego/ bárbaro seria de todo inexistente: não só a "primitiva linguagem helénica” soaria indistinta das linguagens bárbaras aos Gregos contemporâneos, como se assinalam indícios de os primeiros habitantes da Hélade acreditarem apenas em deuses "que são hoje os de muitos bárbaros” $(397 \mathrm{c}-\mathrm{d})^{(62)}$. Não por acaso, o exemplo do tear, que atrás analisámos, é referido neste contexto de discussão sobre a linguagem. E vale a pena lembrar que o Político, provavelmente um dos últimos diálogos, rejeita, pela sua desproporção lógica e pragmática, a divisão inicial dos seres humanos entre "Gregos” e "Bárbaros" ( 262c-263d).

É, portanto, à luz de um preconceito generalizado, e talvez promovido pela retórica fácil dos "discursos de Estado", que deverá entender-se, no Menéxeno, a defesa de uma superioridade dos Gregos com fundamento na raça ou nascimento (genos), que remete para a physis "natureza”. Platão esmera-se visivelmente em tirar partido dos efeitos absurdos a que a mensagem pode chegar: o "purismo racial" que a iónia Aspásia reclama para os Atenienses não se traduz apenas (e, por vezes, contra a verdade histórica) na recusa de qualquer proximidade ou entendimento com os Bárbaros, mas

(61) No artigo referido na nota 9, Gomme faz uma análise ilustrativa de equívocos vários que a noção grega de eleutheria tem suscitado em alguns comentadores, desde Benjamim Constant, equívocos sobretudo derivados da indistinção entre conceito de "liberdade política" e "liberdade individual" (identicamente ao que se passa com o termo isonomia "igualdade perante a lei”, também com entendimentos diversos em Esparta e em Atenas).

${ }^{(62)}$ Também neste ponto é óbvia a influência de Tucídides, segundo o qual os Gregos antigos viveriam como os Bárbaros actuais: cf. supra n. 6, p. 269. 
sobretudo na sofisticada denúncia da "origem espúria" dos demais povos gregos ${ }^{(63)}$, a quem se não perdoam as alianças com o Grande-Rei, destinadas a autoprotegerem-se ou a fazer valer as suas inimizades contra outros Gregos (em especial Atenas).

Uma das alianças mais significativas foi, já em pleno séc. IV a.C., a Paz de Antálcidas (386 a.C.), que teve como principais negociadores Esparta e o soberano persa. $\mathrm{O}$ tratado estipulava a entrega ao Grande-Rei de cidades gregas do continente asiático, cuja defesa Atenas assumira intransigentemente ao longo do século anterior. Embora recusando de início tal cláusula, a exdetentora da Simaquia Iónica, isolada e desgasta pela Guerra do Peloponeso, teve, por fim, de capitular ${ }^{(64)}$.

Nada, no discurso, faz no entanto supor a humilhação que representou, para o orgulho nacional, a Paz de Antálcidas (Aspásia atribui-a, pelo contrário, às diligências do Grande-Rei, pressuroso em travar a hegemonia dos Lacedemónios com o auxílio dos Atenienses ...). Mas é, de facto, o orgulho ferido de Atenas que, quase ao finalizar o elogio (245c-d), se revê no desforço possível que a tradição mitológica permite tirar dos restantes povos gregos - pouco antes, e noutro contexto, "irmãos de língua e de raça" (homoglosson, 242a; homophylon, 242d, 244a):

"Tal é o sentido de nobreza e de liberdade do nosso Estado: firme, inalterável e unido a uma congénita aversão pelo que é bárbaro (misobarbaron): isto, porque somos genuinamente gregos, sem enxertia de sangue bárbaro. Não há entre nós Pélopes, Cadmos, Egiptos ou Dânaos a partilharem a nossa vida, nem tantos outros que são por natureza (physei) Bárbaros e apenas Gregos por força da lei (nomoi): nós somos Gregos dos pés à cabeça, não temos promiscuidades com Bárbaros, e daí a aversão genuína (katharos) que a nossa cidade nutre por uma natureza a ela alheia (allotrion)”

${ }^{(63)}$ Que o jogo político se prestava, mesmo em Atenas, a raciocínios na base da "origem espúria" dos adversários, pode deduzir-se do Alcibíades I onde Sócrates faz ver ao "discípulo" que os primeiros adversários a vencer são os recém-chegados a Atenas e à política: esses que chegam, ainda "a falar como bárbaros" (barbarizontes), para adular o povo e não para o gevernar" (120a-b).

${ }^{(64)}$ As negociações que culminaram na Paz de Antálcides duraram anos. Remetemos outros pormenores para N.G. Hammond, A History of Greece to 322 B.C. (Oxford, 1991) pp. 457-465, que de resto constituiu um suporte histórico valioso para outras visões de conjunto. 
Não é o único exemplo que a obra platónica fornece dos riscos de uma apropriação abusiva da ideia de physis, aplicada à realidade humana. Também Polo e Cálicles, no Górgias, fazem passar ao crivo da relação physis/nomos os conceitos socráticos de "justo" e de "injusto" - aqui não já para intensificar e sim subverter o sentido comum do binómio grego/ bárbaro, à luz do qual os Gregos procuravam idealmente aferir (como o Menéxeno comprova) um "modo de ser helénico". A nova dicotomia que se lhe sucede - a dos mais fortes e dos mais fracos - adquire mesmo uma essência "anti-grega". $\mathrm{O}$ "direito do mais forte", que sanciona os crimes de Arquelau para se apoderar do reino da Macedónia (470d-471d), é o mesmo que justifica e aparentemente aplaude as invasões pelas quais Dario e Xerxes procuraram anexar a Hélade ao império persa e escravizar os Gregos (483e):

\begin{abstract}
"Que outro direito tinha Xerxes para vir fazer guerra à Grécia, ou seu pai aos Citas? E, como este, podia citar um sem número de exemplos. É que estas pessoas, a meu ver, agem segundo a natureza da justiça (kata physin ten tou dikaiou) e, por Zeus, segundo a lei da natureza (kata nomon ton tes physeos), que não é, certamente, igual àquela que criámos ..." ${ }^{(65)}$
\end{abstract}

Nomos em oposição a physis representa, neste contexto, não a referência jurídica ou apenas normativa que revelou desde cedo a propensão helénica para teorizar os seus modelos de organização da pólis, mas tão-só a convenção, ditada pelos mais fracos, com vista a abafar o "direito natural" dos mais fortes.

Não cabe aqui referir as soluções que o platonismo buscou para a resolução do equívoco. Interessa apenas sublinhar como a vivência radical da oposição physis/nomos, nos termos em que o Górgias a apresenta, põe em risco a sobrevivência do Estado e dos indivíduos que a ele pertencem. As naturezas mais dotadas - logo, as "mais fortes" - são justamente, como se aponta na República (VI, 495a-c), aquelas que, por falta de orientação correcta, mais facilmente resvalam na ambição do poder ilimitado, com as consequências trágicas que as décadas anteriores à feitura do Górgias documentam para Atenas.

${ }^{(65)}$ Trad. de M.O. Pulquério, Platão. Górgias (Lisboa, 1992) p. 119. Reproduzimos o comentário pertinente do tradutor, em nota da mesma página: "Falar dos "direitos" de Xerxes à invasão da Grécia é exprimir uma opinião chocante que revela, da parte de Cálicles, uma mentalidade deformada em matéria de consciência nacional”. 
Não surpreende, assim, a menção, só na aparência anódina, que Sócrates faz de Alcibíades, ao iniciar a conversa com Cálicles $(481 \mathrm{~d})^{(66)}$. O principal responsável pelo desastre da expedição à Sicília, que, a partir de 415 a.C., assinala o gradual declínio de Atenas no panorama político grego, é um exemplo claro (e reiteradamente sugerido por Platão) de uma natureza superior, que os estímulos errados do meio e o excesso de convicção pessoal facilmente pervertem. Mas, se a generalidade dos diálogos se limita à insinuação, mantendo a verosimilhança de um Alcibíades anterior a 415 a.C., já o diálogo denominado Alcibiades $I$ abre um horizonte mais largo sobre a experiência negativa que Alcibíades representou para Atenas.

A desmontagem freudiana a que Sócrates submete os sonhos de poder mais caros do "discípulo" supõe já uma reflexão a posteriori sobre o empreendimento de 415 a.C., que a capacidade de persuasão e a ambição irrefreável de Alcibíades lograram impor a Atenas. Ao longo da $1^{\underline{a}}$ parte do diálogo sente-se essa ambição "crescer”, deixar à distância o prestígio e o poder de governantes como Péricles, para buscar os verdadeiros alvos de competição nos reis lacedemónios e, em especial, no Grande-Rei (105c):

"Sim, creio que, à excepção de Ciro e de Xerxes, nenhum homem te parece verdadeiramente digno de consideração. Tais são as tuas esperanças ... não é uma suposição, tenho a certeza!”

Com fraco protesto do interlocutor, Sócrates vai desenhando uma physis desmedida, cuja ambição de "dominar" (dynasteuein) se projecta do espaço estrito de Atenas para a Hélade, daí para os povos bárbaros da Europa e finalmente para os da Ásia, percorrendo o sentido inverso da rota de Dario na sua aspiração a "dominar o mundo" (aqui, subentendido num eufemístico pantas "toda a gente"). Esta megalopsychia é a tal ponto forte que Alcibíades preferirá morrer a não a concretizar (105a, c).

O aspecto curioso desta análise é, de novo, a evocação da physis, não 306 já ao serviço da oposição grego/bárbaro e sim da que Cálicles definira entre senhores/escravos. Cabe a Sócrates demonstrar (sem que seja preciso recorrer ao fracasso dos empreendimentos de Dario e Xerxes ...) que essa

(66) Para esse elo intencional entre o Alcibíades platónico e o cálicles do Górgias, cf. J. De Romilly, Alcibiade (Paris, 1995) pp. 244-246 com a remissão aí feita para o passo 519a-b desse diálogo. 
superioridade inata, que Alcibíades reivindica com base numa superlativa kalokagathia (perfeição física e espiritual), aliada à condição familiar (genos), pode não existir só nele: a conjugação physis/genos (ambiguamente, "família" e "povo") caracteriza, por igual, os seus adversários. Mais uma vez, como no Menéxeno, o recurso arbitrário ao argumento mitológico está presente, associando-se a considerações genealógicas - mas para defesa de uma tese contrária: nem os reis lacedemónios nem os reis persas (descendentes, uns e outros, de Perseu, filho de Zeus - 120e) são de raça ou nascimento (genos) inferior a Alcibíades e aos Atenienses em geral; ostentam, pelo contrário, vantagens significativas, que lhes advêm dos cuidados prestados, quer ao seu nascimento quer à sua educação $(121 b)^{(67)}$.

Sócrates não necessita de argumentos "reais". O quadro psicológico descrito no Alcibiades I evoca impreterivelmente ao leitor a expedição de 415 a.C. à Sicília, que Alcibíades fez aprovar contra a voz autorizada de generais experimentados como Nícias. O fracasso desta não apenas pôs termo à carreira política do pupilo de Péricles mas também às veleidades que Atenas podia ainda alimentar de se sobrepor a Esparta.

\section{Diálogos da $3^{\mathrm{a}}$ fase (Últimos diálogos)}

\subsection{Atenas no CONTEXTO helÉnico}

\subsubsection{ATENIENSES E XENOI}

Paralelamente a uma inflexão de tópicos, interesses e metodologias, os diálogos posteriores de Platão estruturam-se já num distanciamento visível do quotidiano ateniense. A riqueza de pormenores, que faz do Protágoras ou do Banquete expoentes clássicos da vida social e cultural da cidade ao tempo de Sócrates, diminui na proporção em que também o protagonista

${ }^{(67)}$ A obra parece-nos reflectir a influência simplista da Ciropedia e da apologia da "educação de príncipes" que Xenofonte faz remontar a uma época de esplendor persa (a contrastar com a perspectiva crítica que Platão apresenta nas Leis e na Carta VII: cf. infra, pp. 51 e 53, com as notas 85 e 87). De notar, por outro lado, o contraste entre o Sócrates do Alcibíades I e o do Teeteto, que abertamente recusa uma ideia superioridade humana baseada em pergaminhos de família ou de raça (genos): vide infra, p. 327 sqq. 
dos primeiros diálogos se vai confinando a um papel cada vez mais reduzido, que a sua ausência nas Leis parece confirmar.

Algo, aliás, dessa diluição do Sócrates platónico se faz já intencionalmente sentir, quer no Parménides, onde o estatuto tradicional de "mestre" passa ao de "discípulo" dos representantes da Escola Eleática, quer na introdução de uma personagem homónima (Sócrates-o-Moço, talvez identificável a um aluno da Academia $\left.{ }^{(68)}\right)$, que tem apenas um recorte presencial no Teeteto e no Sofista, mas intervém como principal interlocutor (leia-se: discípulo) do Estrangeiro de Eleia no Político. Além do caso peculiar do Parménides, e das recriações deliberadas de diálogo aporético no Filebo e no Teeteto, a personagem Sócrates torna-se quase tão-só o ponto de referência de um círculo cultural e filosófico, que assegura a continuidade dramática no intercâmbio entre atenienses e xenoi, já presente em vários dos diálogos ditos socráticos e no Fédon.

A orientação deste último grupo de obras é, porém, diferente, cabendo em geral aos xenoi intervenientes as honras da condução filosófica do diálogo. Assim sucede no Sofista e no Político, cujas explanações, tendentes a uma definição, respectivamente do 'sofista' e do 'político', ficam inteiramente à conta de um inonimado Estrangeiro de Eleia. No Timeu, também Sócrates é dispensado de uma participação activa, visto ter dado já o seu contributo na véspera com o delineamento do Estado ideal, numa visível alusão à República (26e-27a); o encontro presente centra-se na pessoa de Timeu de Lócris, célebre matemático e astrónomo, a quem compete expor os fundamentos científicos e divinos do referido Estado - o que leva ao longo recuo cosmogónico da criação dos seres celestes e do mundo, pelo Demiurgo; a cargo do ateniense Crítias ficará, na reunião seguinte, o desenvolvimento da história primitiva de Atenas e da desaparecida Atlântida, de que se dá um avanço substancial na conversa introdutória (20d-26d) - narrativa iniciada em pormenor, mas não concluída, no longo fragmento do Crítias. De notar ainda em ambos os diálogos a presença de um interlocutor siracusano - Hermócrates - a quem, no projecto inicial, caberia falar após Crítias (Timeu, 20d, Crítias, 108d) ${ }^{(69)}$.

${ }^{(68)}$ Referido por Aristóteles em Met. 1036b25. O nome era comum: a título de curiosidade, refira-se que se registam cerca de 18 'Sócrates' atenienses, contemporâneos deste, e no todo, 196 a partir do desde o séc.VI a.C. (D. Nails, op.cit., p.269).

${ }^{\left({ }^{99)}\right.}$ Sogro de Dionísio I, Hermócrates é aqui representado como contemporâneo e hóspede de Crítias IV (o Crítias do diálogo), que ser o neto de um outro Crítias (III) referenciado na família 
Com esta troca de protagonistas não se terá pretendido apagar a influência de Sócrates na formação de um pensamento pan-helénico - para a qual, aliás, Platão havia já dado a mediatização decisiva. As introduções do Parménides e do Teeteto, dramaticamente distanciadas em décadas dos diálogos reproduzidos, são exemplo de como as "palavras de Sócrates", oralmente ou por escrito (caso do Teeteto), passam na obra platónica como uma espécie de património comum dos Gregos. Antifonte é ainda capaz de repetir, na sua velhice, uma encontro famoso entre Sócrates, Parménides e Zenão, que lhe fora contado pelo seu amigo Pitodoro, então jovem discípulo de Zenão; fá-lo mais uma vez no Parménides, a pedido de Céfalo de Clazómenas, que vem expressamente procurá-lo, de visita a Atenas, com outros compatriotas seus; no Teeteto, Euclides de Mégara, chocado pela iminência da morte do antigo discípulo de Teodoro de Cirene - que Atenas destacara para Guerra de Corinto - revela ao seu amigo Térpsion a reprodução escrita de um diálogo havido muitos anos antes entre o então jovem Teeteto e Sócrates ${ }^{(70)}$.

Se atendermos a que personagens como Teodoro de Cirene (presente, além do Teeteto, no Sofista e no Político) e Timeu de Lócris, protagonista do diálogo homónimo, constam de uma tradição de mestres com quem Platão, após a morte de Sócrates, terá prosseguido os seus estudos de matemática e de astronomia, não parece abusivo deduzir um novo significado dramático nos xenoi que agora intervêm ${ }^{(71)}$.

de Platão. Crítias IV foi [conhecido como um dos membros] da "oligarquia dos 30 ", formada em 404 a.C. e derrubada um ano depois. Baseando-se nos elementos prosopográficos, D. Nails situa a data dramática do Timeu por volta de 429 a.C. (op.cit., pp. 106-109. Cf. p. 244, onde se insere uma reconstituição da árvore genealógica de Platão).

(70) Teeteto, distinto matemático, também fez parte do corpo docente da Academia. O diálogo homónimo constituirá provavelmente uma homenagem a este colaborador, entretanto morto na sequência de uma das duas guerras de Corinto em que Atenas se envolveu - com toda a probabilidade, a de 369 a.C.: vide D. Nails, op.cit.s.v.

${ }^{(71)} \mathrm{Na}$ esteira da tese de Mattei em L'Étranger et le simulacre. Essai sur la fondation de l'ontologie platonicienne (Paris, 1983), H. Joly chama a atenção para o simbolismo da figura do Estrangeiro anónimo, nos últimos diálogos, em função de uma "filosofia do Outro" que o Sofista vem "legalizar", ao reconhecer O Outro ou O Diferente (thateron), a par de O Mesmo (tauton), como categorias do Ser (254b-255e): vide "Le problème des étrangers", esp. pp. 89-95. 


\subsubsection{A ACADEMIA E A EXPERIÊNCIA SICILIANA}

As décadas iniciais do séc. IV a.C. vão registando para Atenas uma crescente perda de influência na cena política que se reflecte num esbatimento da sua vivência cosmopolita. A cidade não é já o árbitro cultural que, na pessoa de Sócrates, questiona, recusa ou aceita doutrinas e novidades trazidas pelos estrangeiros das mais variadas formações e lugares da Grécia. Perto de Atenas, mas suficientemente distanciada pelos interesses que a motivam como comunidade científica e filosófica, a Academia passa a ser o centro em função do qual se projectam os xenoi dos últimos diálogos.

Sem pormenorizar as circunstâncias que determinam o seu aparecimento fictício, a relevância que aí lhes é dada não pode deixar de associar-se ao convívio com mestres reputados, alguns dos quais Platão foi recrutando, a título provisório ou permanente, para assegurar e inovar o ensino da Academia. Entre os mais brilhantes contavam-se matemáticos, como Eudoxo de Cnidos e Heraclides do Ponto que, no dizer de Field, "fizeram da Academia o centro real do estudo da matemática na Grécia" ${ }^{(72)}$ e aos quais se deve um conjunto de investigações, na área da astronomia, sugeridas e partilhadas pelo próprio Platão. Também entre os discípulos há notícia de uma quota significativa de estrangeiros - tudo leva a crer que em plena igualdade de estatuto, relativamente aos companheiros atenienses: alguns deles vieram mesmo a fazer parte do corpo docente da Academia, como Xenócrates da Calcedónia que, a par de Espeusipo (sobrinho de Platão), terá uma ou outra vez assegurado a administração da Escola, na ausência do seu director; ou Aristóteles de Estagira, que mais tarde fundou a sua própria instituição de ensino - o Liceu.

A projecção que a Academia foi adquirindo no mundo grego contou com outros factores. Um deles, como se referiu já, foram os estudos aí desenvolvidos em matéria de teoria política e de legislação; de acordo com testemunhos antigos (e são variados), tanto Platão como outros membros foram várias vezes solicitados para elaborar constituições destinadas ao aperfeiçoamento de sistemas legislativos ou à fundação de novas cidades - nomeadamente, colónias. Por outro lado, as demoradas viagens de Platão a partes distantes da Hélade, como a Magna Grécia e a Sicília, fomentaram laços de amizade pessoal e intelectual com personalidades destacadas, como

${ }^{(72)}$ Plato and his contemporaries (London, 1967) (repr. 1930), p. 41. 
o pitagórico e estadista Arquitas de Tarento ou Díon, sobrinho do tirano Dionísio I de Siracusa, que se mantiveram sempre vivos: mesmo que as Cartas, na totalidade ou apenas algumas delas, não sejam autênticas, o seu testemunho é, nesta matéria, credível. ${ }^{(73)}$

Mas esta consagração da Academia como instituição pan-helénica (que se manteve até ao período romano, não obstante a concorrência de outras escolas posteriores, nomeadamente o Liceu) não assenta exclusivamente no intercâmbio filosófico e científico que em parte a motivou. Ainda a crer nas Cartas, o empenho do seu fundador na solução de situações delicadas, que afectaram em especial a Sicília, terá tido parte importante nesse prestígio.

A Carta VII menciona três estadias em Siracusa - uma, anterior à fundação Academia (388/387 a.C.) e duas já depois, datando-se a última à volta de 361 a.C. ${ }^{(74)}$. Não obstante reveses e frustrações que ficaram de todas elas - as duas últimas, a instâncias do próprio tirano Dionísio II, tio de Díon -, Platão acompanhou activamente a situação política da ilha, como em geral a dos Gregos da Magna Grécia, a quem ficou ligado por laços fortes de hospitalidade. Aquando da terceira viagem à Sicília, a influência positiva que dele se esperava vence os sentimentos de aversão à tirania e, concretamente, a Dionísio II, que anos antes havia sujeitado Díon, seu tio, ao exílio e à confiscação dos bens. A Carta VII dá-nos conta dos motivos que levaram Platão a aceitar uma viagem, de cujos riscos pessoais estava bem consciente (339d-e):

\begin{abstract}
"Outras cartas - de Arquitas e dos Tarentinos - me vieram parar às mãos, a enaltecer o empenho de Dionísio na filosofia; diziam ainda que, se desta vez me recusasse a ir, cairiam por terra todos os laços de amizade que haviam estabelecido com Dionísio por meu intermédio - o que, em matéria de política, não era de somenos importância /.../; também gente de Atenas me pressionava com rogos idênticos e era frequente ouvir a mesma recomendação: que não devia trair Díon nem os meus hóspedes e amigos de Tarento (xenous te kai hetairous)."
\end{abstract}

As diligências diplomáticas de Platão, no sentido de minorar a dureza do regime tirânico protagonizado por Dionísio II e criar um clima propício

(73) Cf. supra, n. 25.

(74) Nails (op.cit., pp. 246-24.6) defende, para Patão, uma data de nascimento anterior à tradicional em cerca de quatro anos (c.348/7) e situa a primeira viagem à Sicília quatro anos mais tarde, c.384/3 a.C. 
à aceitação de de "leis iguais" para todos (isonomia, 336c), não tiveram êxito. Independentemente, porém, desse facto, é de realçar o sentido de solidariedade que vinculou Platão a esta parte do mundo grego, solidariedade reflectida, quer a nível das obrigações contraídas como hóspede, quer da complexidade política que faziam da Sicília uma verdadeira "ilha" da Grécia, mais vulnerável que qualquer outra região à ameaça dos Bárbaros, quer os de Itália (Oscos) quer os do Norte de África (Cartagineses). Daí, e já após a queda de Dionísio II e a morte à traição de Díon, o incitamento reiterado aos familiares e partidários de Díon para procurarem a conciliação entre as duas facções, pró-tirania e pró-democracia, sob pena de, a curto prazo, serem ambas aniquiladas (Carta VIII, 353e):

"Se um tal horror - aliás, plausível - vier a acontecer, toda a Sicília ficará privada da língua grega e cairá nas garras e na sujeição de Fenícios e Oscos.”

A reflexão é sobremodo interessante na sua formulação, ao evidenciar a equivalência absoluta que se estabelece entre 'pátria' e 'língua'. Talvez que o regime tirânico, que até então dominara na Sicília, secundarizasse todas as outras afinidades presentes na ideia de uma "nação grega", comum aos demais povos e regiões da Hélade - nomeadamente, a eleutheria "liberdade" e a isonomia "igualdade" (política). Mas não é inviável que essa ideia pudesse, para Platão, resumir-se à modalidade que verdadeiramente a comunicava - ou seja, a língua grega (também Fernando Pessoa dirá, mais de vinte séculos depois, "a minha pátria é a língua portuguesa").

Voltando ao contexto da carta, é de sublinhar a atitude diplomática do fundador da Academia, que entendeu deverem os Sicilianos procurar entre si, tanto quanto possível por meios pacíficos, uma solução para o conflito que ameçava degenerar em guerra civil. Uma sugestão alternativa, particularmente curiosa, é a de que Gregos de outras regiões da Hélade sejam chamados a ajudar à implantação de um regime democrático na Sicília. A Carta VII refere em especial os Gregos do Peloponeso, mais próximos do ponto de vista étnico e linguístico, e dotados de modelos governativos para os quais sabemos que vão as preferências platónicas; mas a possibilidade abre-se a Gregos de outras partes, como Atenas, que é expressamente citada ${ }^{(75)}$.

${ }^{(75)}$ Também a Cidade dos Magnetes, nas Leis 708a contará com cidadãos de toda a Grécia: o exemplo histórico mais famoso desta convergência é o de Túrios, perto de Síbaris (na Sicília), cidade para a qual Péricles recrutou colonos de toda a Grécia (nota de Édouard des Places in Platon, Oeuvres complètes, tome XI. Les Lois III-VI, p. 53). 
A sugestão indica, por si, que não se trata da tradicional ajuda militar (que Platão, por princípio, rejeitava ${ }^{(76)}$ ) e sim da colaboração activa de cidadãos de outros Estados na vida dos Sicilianos e no reforço das defesas da ilha.

Nesse conceito lato de cidadania se inspirou a actuação política de Platão - na realidade, mais ampla do que lhe é em geral reconhecido. Por seu intermédio (embora não exclusivo), Díon encontrou apoio e acolhimento em Atenas, chegando mesmo a receber o oferecimento de membros da Academia para combater a seu lado contra Dionísio II; e não deixa de ser significativo que, em plena crise de facções que se digladiam pelo poder, seja a Platão que os Siracusanos ligados a Díon e ao partido democrático recorrem. É, pois, bem provável que, sem o seu papel medianeiro, a ilha tivesse caído num isolamento total, em consequência de um regime tirânico que a quase totalidade dos Gregos não aceitava já ${ }^{(77)}$.

\subsubsection{UMA NOVA VIVÊNCIA DE XENIA}

As estadias na Magna Grécia e na Sicília, bem como o acompanhamento pormenorizado do drama político e humano dos Sicilianos associamse estreitamente, em Platão, à vivência da Academia, a instituição que em Atenas acolhe, na mesma aura reverencial de hóspedes (xenoi), os estrangeiros que a procuram e nela colaboram. À margem do Sócrates competitivo dos primeiros diálogos que, conscientemente ou não, marca a supremacia de Atenas sobre os seus visitantes, a oposição atenienses/xenoi dá lugar a uma afinidade de objectivos, interesses e formas de interagir que recupera o sentido inicial de xenia: uma relação de hospitalidade entre membros de comunidades diferentes, com base em sentimentos recíprocos de amizade e entreajuda.

A introdução do Sofista é reveladora desta inflexão de atitudes que, não obstante o tom paródico de reminiscências óbvias da Odisseia, tem a guiá-la a autoridade do "deus dos hóspedes e dos estangeiros" (to xenion ... theon, 216b). Do ponto de vista dramático, o que se pede ao Estrangeiro é que

(76) A Carta VII sublinha várias exortações feitas a Díon para que não enveredasse pela luta armada que, a seu ver, só agravaria a situação dos Sicilianos, tendo Platão contrariado abertamente essa iniciativa (350b-d).

(77) O Discurso Olímpico de Lísias, proferido em Olímpia em 388 a.C., revela sentimentos tão hostis para com a tirania siciliana e o seu representante (Dionísio I) quanto para com os Persas: cf. J. Ribeiro Ferreira, Hélade e Helenos, pp. 475-477. 
explique o que "lá", em Eleia (isto é, na sua terra - to ekei topos, 217a) as pessoas pensam, e que nomes dão, respectivamente ao sofista, ao político e ao filósofo.

A versão "eleática" que no diálogo o Estrangeiro propõe para 'sofista' (que em conversas futuras se alargará à de 'político' e à de 'filósofo' ${ }^{(78)}$ ) vem já depurada da componente erística, cuja prática a tradição faz remontar sobretudo a Zenão; é com esta credencial que Teodoro apresenta a Sócrates o Estrangeiro, sugerindo um eleatismo "moderado" (isento de hybris "excesso" ) e, como o próprio demonstra, capaz de uma crítica isenta aos pressupostos da doutrina em que se filia (216b). Ao contrário, também, dos eleatas, chefes de Escola, no Parménides, o Estrangeiro não abraça confiantemente a tarefa que lhe é pedida; reconhece as dificuldades e é sobretudo o sentimento das suas obrigações como hóspede que o leva a aceder: não o fazer seria uma atitude incivilizada - ou seja, no sentido etimológico que o contexto torna obrigatório, "imprópria de um hóspede" (axenon, 217e).

Como se observou ao longo deste volume, o intercâmbio entre a dupla vivência de polites "cidadão" (na pólis originária) e xenos (em outras póleis), que é a de todo o grego que viaja por outros Estados da Hélade, reforça-se deste modo através da identificação de um valor genérico - "político" no sentido original do termo - à noção precisa de xenia que faz, por igual, do polites um xenos "hóspede/ hospedeiro", como se viu a propósito do Ménon.

Terá sido essa, a nosso ver, a intenção última das Leis ao substituir o lugar convencional dos diálogos - Atenas - por Cnossos. Sem excluir outros intuitos (que poderão deduzir-se, nomeadamente da ausência de Sócrates), é significativo que o encontro decorra em Creta, tradicionalmente "o berço dos sistemas legislativos gregos" (79), e que o anónimo Ateniense o protagonize agora, na condição de Estrangeiro. Com essa alteração à rotina pretender-se-á irradiar qualquer suposta vantagem que o cenário de Atenas pudesse conferir à figura principal do diálogo; mas ter-se-á, sobretudo, em vista a experiência de xenos vivida pelo ateniense Platão nas suas viagens pela Grécia e, em especial, pelo sul de Itália e Sicília: só ela permite, no confronto pessoal das divergências inerentes a variações étnicas e geográficas,

${ }^{(78)}$ Desse projectado tríptico, o Filósofo não chegou a ser concretizado.

(79) A ideia de Creta como primeiro e o mais conseguido modelo legislativo grego ocupa parte substancial do Minos, um dos diálogos considerados apócrifos (cf. e.g. 315c). 
aferir o que cada uma pode trazer ao melhoramento recíproco e ao reforço das afinidades substanciais que explicam a indentidade dos Estados gregos como 'nação'.

Cabe aqui dizer, contudo, que a ideia de uma união política da Grécia só excepcionalmente e sem convicção aflora na obra platónica - concretamente, no livro III das Leis, a propósito dos Dórios do passado. O Estrangeiro Ateniense formula-a sob forma de pergunta retórica: se os três Estados dóricos do Peloponeso tivessem conseguido respeitar os propósitos iniciais, "não teriam constituído uma aliança duradoura que os salvaguardasse para todo o sempre, de molde não só a manterem a sua liberdade como a impor a outros o seu domínio se assim o desejassem e, em resumo, a fazer o que lhes apetecesse, entre todos os homens, quer fossem Gregos ou Bárbaros?” (687a-b)

Mesmos nas grandes obras legislativas, Platão não abdica do estatuto carismático da pólis grega, isto é, da cidade-Estado, não sendo excepção ao conhecido "particularismo grego", que para comentadores vários representa o inacabamento de um projecto político e civilizacional dos Gregos. Como J. R. Ferreira sublinha, o sentido global de "nação", em que ao longo da sua história os diversos povos gregos foram convergindo, preenche-se plenamente na noção de to hellenikon dada já por Heródoto (8.144) e retomada no livro IV das Leis por Platão: uma unidade de sangue, de língua, de religião, de ritos e costumes que não necessita (nem deseja) uma uniformidade de natureza política ${ }^{(80)}$.

O facto é tanto mais de relevar no criador das Leis quanto é certo, nas suas obras maiores de teorização política, encontrarmos propostas polémicas, por vezes bem ao invés de práticas e conceitos fortemente enraizados na mentalidade helénica. Note-se ainda que o seu distanciamento da vida política ateniense, bem como, nos últimos diálogos, a visível diluição da supremacia de Atenas, através de uma maior ênfase dada às experiências e "saberes" dos xenoi aí intervenientes, não implica o esbatimento de elos afectivos e até "políticos" em sentido amplo, que Platão sentiu sempre pela sua cidade de referência.

A juntar ao convicto elogio de Atenas com que, nas Leis, o cretense Clínias e o espartano Megilo agraciam o Estrangeiro Ateniense, há o testemunho pessoal da Carta VII onde, em termos emotivos inesquecíveis,

${ }^{\left({ }^{80)}\right.}$ Vide Hélade e Helenos, em especial pp. 107-109. 
Platão desagrava Atenas dos ataques e das insinuações caluniosas que surgiram na sequência da morte à traição de Díon, perpetrada por dois dos seus hóspedes atenienses:

“E não tendes que temer de Atenas: há ali gente que em matéria de excelência está à frente de todos os homens e que odeia quem se aventura a assassinar um hóspede seu ... “ (336d).

\subsection{Atenas e Bárbaros}

\subsubsection{LinHAS DE EVOLUÇão}

Paralelamente a um reforço dos laços de afinidade entre atenienses e xenoi (mesmo que idealmente estimulados pela vivência específica da Academia), os últimos diálogos platónicos caracterizam-se por uma preocupação, relativamente ao mundo exterior dos Bárbaros, não só por captar a sua diversidade, individualizando-os, mas também por salientar aspectos comuns aos Gregos, ou até de algum modo paradigmáticos.

Já no Fédon se detecta o aviso contra os riscos de uma avaliação generalizada ou preconceituosa de "Bárbaros", quando Sócrates alvitra que se procure o "homem de virtude" requerido não só entre os Gregos mas também entre as nações bárbaras, que são numerosas (polla, 78a) - e, como tal, diversas. É esta a ideia que se explicita no conhecido passo do Político onde a "lição de lógica" ${ }^{(81)}$ sobre o método das divisões remete para inconsequência de uma alternativa grego/ bárbaro:

"Se se quiser dividir em dois o género humano (genos athropinon) a maior parte das pessoas daqui começará logo por pôr de um lado a raça helénica, considerando-a como uma unidade distinta de tudo o mais, e do outro, todas as outras raças, muito embora estas sejam uma infinidade que não se mistura nem se entende entre si! Mas, como as qualificam com o único nome de "Bárbaros", julgam que fazem uma única raça (263c-d).”

${ }^{(81)}$ Expressão de A. Diès na edição bilingue das Belles Lettres: Platon, Oeuvre Complète. Le Politique, (tome IX) p. 9. 
A oposição grego/ bárbaro, cujo radicalismo assenta no choque de culturas entre o continente asiático e o europeu que as invasões persas vieram despoletar, dá lugar a uma percepção mais atenta à diversidade dos povos bárbaros e suas referências civilizacionais ${ }^{(82)}$, que de algum modo retoma o posicionamento objectivo das Histórias de Heródoto. Para tal contribuiu não só a assimilação gradual das Histórias de Heródoto (a juntar a relato de outros viajantes) como o incremento de contactos políticos e culturais mais consistentes com o Norte de África e a Ásia Menor ${ }^{(83)}$.

Deste surto de interesse pelos povos bárbaros resultam análises históricas e sociológocas que, embora não integradas ainda na $1^{\underline{a}}$ e na $2^{\underline{a}}$ fases dos diálogos platónicos (mais atentos à recriação da ambiência do séc. V a.C.), penetram sensivelmente na última fase, acompanhando de resto as tendências da hitoriografia e da retórica, nas primeira décadas do séc. IV a.C.

É o caso concreto de Isócrates que, no Busíris, dá lugar ao fascínio pelo exotismo egípcio, já consolidado no sécuo anterior, como a tragédia euripidiana o comprova; ou de Xenofonte, cuja experiência asiática como chefe de tropas expedicionárias gregas que em 401 a.C. apoiram a causa de Ciro-o-Moço contra seu irmão Artaxerxes se traduziu em obras sedutoras pela novidade, quer sobre a Pérsia contemporânea, na Anábase, quer sobre os Persas antigos (Ciropedia).

Dado que são estes o povos que nos últimos diálogos se destacam, com algum significado para a cultura grega, iremos analisá-los separadamente.

${ }^{(82)}$ Compare-se a classificação estereotipada de Rep.IV 435e-436a - que distingue os Citas e os Trácios pela irascibilidade, os Gregos (talvez ...) pelo gosto ao saber ou os Fenícios e Egípcios pelo amor às riquezas -, com a pormenor descritivo de atitudes de vários povos face à embriaguês, em Lg. 637d-e: os "rótulos" dão lugar a uma especificação de comportamentos civilizacionais diversos, mesmo numa posição genericamente comum.

Sobre a abertura do texto de Heródoto à diversidade étnica e sua valorização vejam-se as análises recentes de $M^{\mathbf{a}}$.F. Sousa e Silva, "O desafio das diferenças étnicas em Heródoto: uma questão de inteligência e de saber", e de Cármen Soares, "Tolerância e Xenofobia ou a consciência de um universo multicultural nas Histórias de Heródoto”, ambas em Humanitas 53 (2001), respectivamente pp. 3-48 e 49-82.

${ }^{(83)}$ As viagens a um e a outro dos continentes estavam já relativamente estandardizadas, como se subentende dos preços fornecidos no Górgias (511) para viagens ao Egipto ou ao nordeste europeu e ainda da referência ocasional a curiosidades locais de ambos os continentes, provavelmente incluídas em roteiros turísticos: vide Luc Brisson," l'Égipte de Platon" in Lectures de Platon, pp. 157-159. 


\subsubsection{Os Egípcios}

Embora relativamente tardios (séc. I a.C.), os testemunhos que associam o Egipto aos locais visitados por Platão afiguram-se bastante plausíveis. Em contraste com anotações de passagem, como a do Menéxeno, sobre a tentativa de conquista do Egipto pelos Persas ou a do Fédon (80c), alusiva às múmias, os últimos diálogos, precedidos pelo Fedro, apresentam referências não só de certo destaque argumentativo mas também coerentes com uma visão civilizacional estruturada.

Essas referências não ultapassam objectivamente o caudal de informações a que o ateniense culto do séc. V a.C. tinha já acesso, através do Livro II das Histórias de Heródoto. Em contrapartida, há em Platão um aproveitamento reflexivo de dados específicos que, pelo menos num caso, pode interpretar-se como decorrente de observação pessoal e in loco. A esse âmbito me parece entendèr-se a descrição pormenorizada de métodos e jogos egípcios para ensinar matemática às crianças, que encontramos em Lg.VII 819 b-c. Não obstante críticas que em 747 c-d se levantam quanto à orientação "materialista" desse ensino (como, de resto, entre os Fenícios e outros povos não mencionados), o passo em causa consagra o aplauso por técnicas pedagógicas cuja eficiência e até qualidade científica supera de longe os métodos gregos. $\mathrm{O}$ seu rigor merece mesmo o seguinte comentário:

“Caro Clínias, fiquei pasmado de todo, ao aperceber-me tão tarde das nossas falhas nesta matéria! /.../ Senti vergonha, não apenas por mim mas por todos nós, Gegos!”

É de algum modo o diálogo com a tradição egípcia que está presente também na lenda da invenção da escrita, atribuída (entre outras invenções, como a astronomia e o cálaculo) a Theuth no Fedro 274c-275b - referido ainda no Filebo como inventor da gramática, 18b-d. As perplexidades que Platão, por intermédio de Thamous, rei de Tebas do Egipto (identificado ao deus egípcio Ámon), faz sentir, com respeito à invenção de Theuth, têm certamente a ver com o o uso "fechado" da escrita entre os Egípcios, que L. Brisson releva com pertinência a propósito do Timeu 23a-b: na óptica dos sacerdotes egípcios, o reconhecimento da imprescindibilidade da escrita para a transmissão de eventos passados limita-se ao papel de "controle" de 
uma tradição oral, que aquela não substitui ${ }^{(84)}$. De facto, a narrativa sobre o status da primitiva Atenas e da sua vitória contra as pretensões imperialistas de Atlântida, cerca de nove mil anos antes, é feita exclusivamente sob forma de um relato oral que corresponde, ponto por ponto, à versão escrita nos Livros guardados no templo.

Independentemente da possibilidade de uma viagem ao Egipto ter inspirado a Platão o fictício encontro de Sólon com os sacerdotes de Sais ${ }^{(8.5)}$, no Timeu, é pelo menos claro que as reflexões sobre oralidade e escrita, presentes no Fedro, têm tanto a ver com o culto socrático da "palavra viva" quanto com o uso restrito (e hierático) da escrita entre os Egípcios. Nada impede que ao secretismo desejado pelas elites político-religiosas do Egipto se associassem razões idênticas àquelas com que o sábio rei Thamous, no Fedro, argumenta em desfavor da invenção do seu súbdito Theuth, em especial os riscos de os homens passarem a substituir pela escrita o único meio apto a manter viva a palavra - ou seja, a Memória ${ }^{(86)} \ldots$

$\mathrm{O}$ aspecto, contudo, que mais parece concitar a admiração pela sociedade egípcia é a capacidade de sobrevivência, ao longo de milénios, de um mesmo modelo organizativo, com o qual o pensamento político de Platão apresenta bastas semelhanças em tópicos fundamentais. Incluem-se nestes a repartição rígida da sociedade em três classes (governantes, guerreiros, povo em geral), a proibição de intercâmbio entre os vários grupos profissionais em ordem a um melhor rendimento ou a recusa de inovações que ponham em causa as leis e o equilibrio social estatuído (como, para Platão, é o caso da arte).

${ }^{(84)}$ Art.cit., pp. 157-159, que articula os passos citados do Fedroe do Timeu com o testemunho da Carta VII, onde Platão proclama a recusa em dar a conhecer a sua filosofia através de qualquer “tratado" (342e-343a). Também H. Joly sublinha a marca platónica que, sob a aparência de um logos aigyptikos a narrativa de Theut condensa: "les critères du jugement porté par le roi contre l'écriture sont empruntés à la théorie platonicienne de la connaissance et de l'éducation" "Platon Égyptologue” in Études platoniciennes. La question des étrangers, p. 100).

${ }^{(8.5)}$ Heródoto menciona a estadia de Sólon no Egipto e um encontro com Âmasis, que lhe teria fornecido sugestões legislativas. Os testemunhos sobre a ocasião dessa viagem (antes ou depois de ter assumido em Atenas funções de arconte) não são conclusivos. Uma discussão pormenorizada deste tópico pode ver-se em Delfim Leão, Sólon. Ética e política, Lisboa, 2001, pp. 246-250.

${ }^{\left({ }^{86}\right)}$ Seria tentador estabelecer uma ligação entre o culto da Memória entre os Pitagóricos e a tradição evocada no livro II de Heródoto e divulgada pelos Egípcios, segundo a qual Pitágoras viajara pelo Egipto e daí importara para a Grécia crenças religiosas, como a metempsicose, fazendo-as passar como suas ... 
No Timeu (24a-c) essa proximidade é conscientemente evocada através discurso que Platão põe na boca dos sacerdotes de Sais: segundo eles, a constituição egípcia é a mesma da Atenas anterior aos cataclismos que, milhares de anos antes, não apenas haviam submergido a ilha de Atlântida como também modficado as condições de vida na Ática (graças ao Nilo salvador, o solo egípcio terá escapado a esses efeitos, permitindo aos povos que habitavam ao seu redor conservar as suas leis originais, 22d-e). Tal semelhança, em especial no que toca a Sais, tem uma razão de ser divina: foi a mesma deusa (Neith em egípcio e Atena em grego) que fundou ambas as cidades e lhes deu as mesmas leis (21e, 23d-24c).

Por sua vez, os ouvintes actuais da narrativa de Crítias descobrem sem custo que as afinidades se estendem também ao Estado cujos fundamentos Sócrates expusera no dia anterior - um fictício laço cronológico que visa claramente a República. Este pormenor, em princípio sem grande relevância, poderá ter um significado específico, face à tradição reportada por Proclo, segundo a qual os contemporâneos de Platão o teriam acusado de plagiar, na República, as instituições egípcias ${ }^{(87)}$. Não é, nessa medida, improvável que o passo em causa do Timeu constitua uma réplica, cuja ironia estará patente na excentricidade de atribuir a Atena ( para todos os efeitos, uma deusa ateniense, mesmo sob o nome de Neith...) pressupostos legislativos que consagram um parentesco mítico entre Atenas e Sais do Egipto.

Se o intuito de subtrair a cidade utópica da República à realidade de sistemas legislativos vigentes não dá margem à especificação de eventuais contributos, quer de Egípcios quer, sobretudo, dos Estados espartanos, já as Leis, como $2^{\underline{a}}$ opção que representam de uma cidade "real" - a colónia dos Magnetes, a fundar por Cnossos (702b-d) -, não apenas acusam a inspiração dórica que lhes serve de matriz, como integram soluções ou aperfeiçoamentos vários, colhidos em outros sistemas legislativos, dentro ou fora da Hélade, que Platão desejou explicitamente mencionar ${ }^{(88)}$.

É assim numa perspectiva de abertura - legislativa mas também no sociológica e religiosa - que se mencionam instruções oraculares a ter em

(87) Apud Katrin A. Morgan, “Designer History: Plato's Atlantis and Fourth-Century Ideology", JHS 118 (1998) 110.

(88) Também na sua concretização futura, a Cidade dos Magnetes prevê a actualização das suas disposições no campo cultural, científico e mesmo educativo, sempre que os modelos observados no estrangeiro pelos seus visitantes se afigurem superiores: para esta importância conferida nas Leis às theoriai, vide H. Joly, "La question des étrangers", pp. 50-52. 
conta previamente à fundação da cidade, instruções essas que poderão indiferentemente provir de Delfos, de Dodona, de Ámon ou de qualquer outro oráculo, celebrizado pela sua antiguidade e pelos seus créditos (738bc); maior latitude parece ainda caber aos futuros rituais religiosos, que tanto poderão respeitar as tradições nativas como adoptar outras geograficamente diversas (e.g., da Etrúria ou de Chipre, 738c).

Releve-se, por este aspecto, o interesse particular que reveste a menção ao oráculo de Zeus Ámon, óbvio testemunho de um processo de aculturação que o estabelecimento da colónia de Cirene, na faixa mediterrânica do Norte de África, veio fomentar. Situado fora da Hélade, em pleno deserto líbio, o oráculo grego africano consagra, a partir da época arcaica, a assimilação do Zeus helénico ao deus Ámon, primitiva divindade local de Tebas que acabou por se identificar ao todo-poderoso $\mathrm{Ra}^{(89)}$.

Face a outros indícios significativos, como os do Timeu (e, eventualmente, da República), é provável que o paradigma da sociedade egípcia esteja também presente na evocação de Zeus Ámon nas Leis. Assinalámos atrás o elogio de práticas pedagógicas egípcias no que toca à matemática, a que se junta a adopção de um modelo social tripartido, que o mito do Timeu destaca igualmente para a primitiva Atenas. É, contudo, nas considerações relativas ao papel da arte, e aos moldes em que deverá ser produzida, que a aproximação ao país do Nilo ganha nas Leis visibilidade.

Enquanto na República se entende suficiente o controlo da actividade artística através da classe dos guardiãos, as Leis, embora mais flexíveis no domínio da criação literária (admitindo mesmo, sob condicionantes, a comédia), noutros, como a pintura, a música ou a dança, advogam a imposição de um modelo hierático, idêntico ao que vigora no Egipto (II, 656d):

"Foi já há muito, segundo parece, que os Egípcios chegaram a esta ideia que estamos agora a enunciar: é mister que a juventude de um Estado se afeiçoe, no seu quotidiano, tanto às posturas belas como às melodias belas. Assim, depois de fixarem quais seriam e em que moldes, publicitaram-nas nos templos; e não era permitido, nem aos pintores nem aos outros artistas, que trabalhassem com qualquer tipo de figuras, fazer inovações ou conceber outras fora dos moldes herdados.”

${ }^{(89)}$ Na Pítica IV, em honra de Arcesilau de Cirene, Píndaro refere o oráculo de Zeus Ámon como uma espécie de "emanação" do oráculo de Delfos (vv.24-28); também no início do Político é Zeus Ámon que Teodoro de Cirene invoca. Par outros pormenores, vide o artigo de Reiss em RE, s.v. Ammon. 
Não são, pois, conceitos estéticos que ditam a apreciação positiva da arte egípcia e sim a sensibilidade do legislador, atenta sobretudo à garantia de uma sociedade estável, governada segundo os melhores ditames. A mútua dependência entre factores sociais e e factores artísticos constitui, por assim dizer, um axioma da teoria política e sociológica de Platão; por isso, a sobrevivência de um modelo organizativo, por melhor que seja, é impensável sem uma correlativa "estabilidade" na arte.

O Egipto tinha assim boas razões para se impor à admiração, não apenas do criador das Leis mas dos Gregos em geral. Foram as suas instituições rígidas que lhe permitiram atingir, milhares de anos antes dos Gregos, um nível complexo e avançado de civilização, patente nos seus registos históricos tal como no progresso técnico, que produções grandiosas atestam. Ainda segundo Heródoto, os Egípcios reivindicavam para eles a origem da filosofia, que terá sido depois difundida na Grécia por viajantes gregos como Pitágoras.

Tudo isto está presente na opinião que os sacerdotes de Sais veiculam, em conversa com Sólon, no Timeu (22b): "Vocês, Gregos, estão sempre na infância! Velho, não pode nenhum Grego sê-lo!” É a eficácia de um tipo de "sociedade fechada" (para adoptar a terminologia de K. Popper ${ }^{(90)}$ ), cuja sabedoria e ancestralidade faz um grego sentir-se "criança", que Platão - por coincidência de achados ou por assimilação consciente - procura também imprimir nas suas criações legislativas. Convirá, porém, não sobrestimar o sentido desta aproximação. Apesar de um idêntico conceito de "sociedade fechada”, que estabelece a ponte entre o modelo egípcio e a cidade platónica, como também os Estados dóricos, há diferenças estruturais que Platão se empenha em realçar.

Um dos aspectos respeita à xenofobia tradicional dos Egípcios que, aliás, a República parece perfilhar no caso "político" mais famoso: a exclusão simbólica do poeta Homero. Mas não é sob forma de autocrítica e sim de censura às instituições egípcias que o problema é reequacionado nas Leis (XII, 953d-e), a propósito do visitante estrangeiro (xenos) que vem encarregado de uma missão oficial: não só a estadia deverá ficar a cargo da

${ }^{(90)}$ The Open Society and its Enemies (London, 1974) (reedição da edição revista de 1962). Embora partindo da assimilação da Cidade platónica ("fechada") aos modernos totalitarismos, as várias remodelações desde a $1^{\underline{a}}$ edição (1947) vão no sentido de valorizar a rejeição platónica da tirania. 
Cidade como caberá aos "notáveis" proporcionar um acolhimento digno, que inclui formas de convívio e conversas de proveito recíproco:

"É segundo estes preceitos que devem ser acolhidos todos os estrangeiros e estrangeiras que nos visitam, bem como os que enviamos às suas terras. Essa é a forma de honrarmos Zeus Hospitaleiro, em vez de procedermos como os filhos do Nilo, que os apartam da sua mesa e dos seus sacrifícios, chegando mesmo a expulsá-los com decretos selvagens."(91)

Não se trata de uma atitude meramente diplomática. A obrigação que a comunidade contrai com os seus visitantes e vice-versa, abrange em princípio todos os estrangeiros (eventualmente, não gregos), inserindo-se na ambiência dos últimos diálogos que analisámos a propósito do Sofista. Zeus Xenios é, como ali, a divindade todo-poderosa que define essas relações numa base de confiança e solidariedade, onde mais uma vez se infiltram ecos da experiência pessoal de Platão - por vezes dolorosa, como vimos já - enquanto xenos:

"Isolado, como está, dos seus amigos e da família o estrangeiro é ainda mais digno de compaixão aos olhos dos homens e aos dos deuses" (730a).

A par da xenofobia, outro aspecto também criticável na organização social egípcia é seu hieratismo extremo. Ao salientar, no Político, a apetência pelo poder que a classe dos sacerdotes e dos adivinhos tende a assumir, o Egipto surge de novo como exemplo negativo:

"Efectivamente, o estatuto dos sacerdotes e dos adivinhos enche-os de um orgulho desmedido e a magnitude das suas funções confere-lhes um considerável prestígio, de tal sorte que, no Egipto, um rei nem sequer pode governar à margem da classe sacerdotal. Mesmo que alguém, vindo inicialmente de outra casta, tome o poder pela força, é mais tarde coagido a integrar-se nesta referida casta” (290d).

A crítica à prática egípcia de ser o poder religioso a legalizar o poder político mantém-se implicitamente, como nota L. Brisson, nas $L e i s^{(92)}$ : é a

${ }^{(91)}$ A nosso ver, o texto não comporta a versão que Brisson apresenta ("en les immolant et en les mangeant ...”, op.cit., p. 167 e n. 2), de preferência às de Robin e Diès: a acusação de os Egípcios matarem e comerem os hóspedes - repudiada por Isócrates no Busíris \$32 - não se ajusta ao nível de civilização que, não obstante críticas, Platão indubitavelmente admira.

(92) Op.cit., p. 163. 
uma Comissão de Vigilância, constituída por filósofos, que incumbe fiscalizar a aplicação das leis e os actos governativos da Cidade dos Magnetes (XII, 953e). A influência sacerdotal não vai além da que os oráculos dão a conhecer previamente à fundação da Cidade ou em momentos importantes. Mesmo quando, a partir do exemplo egípcio, o Estrangeiro Ateniense advoga a aprovação, nos templos, de modelos e regras que as manifestações artísticas da futura Cidade deverão respeitar, não está em causa qualquer princípio hierático, fundado na crença de só eles corresponderem a uma vontade divina (como certamente sucederia entre os Egípcios), mas tão-só o intuito pragmático de evitar consequências socialmente negativas de um instinto de inovar, que Platão reconhece inerente à natureza humana (797d-798d).

Porém, é a outro âmbito de vivência política que, a nosso ver, se insere o ponto de clivagem fundamental entre o Egipto e a Cidade platónica. Ao referir Sais, no Timeu, como a mais importante cidade do Baixo Egipto, Platão insinua (embora o não explicite) que as leis fundadas por Neith são o ponto de partida de toda a organização legislativa do Egipto. Neste, como noutros pontos, é coerente a observação de Brisson quando, em vez do "Egipto em Platão" prefere falar do "Egipto de Platão"(93). Semelhantes, à primeira vista, por um idêntico conceito de "sociedade fechada", os sistemas legislativos platónicos mantêm no conjunto o respeito pela diversidade, que os diferentes povos e Estados gregos foram consciencializando na sua evolução comum e que se reportam, como atrás referimos, ao seu conhecido “particularismo" político ${ }^{(94)}$. Diferentemente do que sucedeu no Egipto (e na maior parte das nações "tradicionais"), não se trata, para Platão, de impor à nação grega uma constituição única e um governo único, e sim de fomentar nos Estados, a mesma "emulação para a virtude" que deve ser apanágio das relações humanas (Leis, 731a).

\subsubsection{Os Persas}

324

Cerca de um século após as invasões bárbaras, a institucionalização de contactos com o Império Persa foi estimulando um conhecimento mais preciso e pormenorizado dos povos da Ásia Menor. A designação genérica de "Grande-Rei" - cobrindo indiferentemente o unificador do Império persa e os seus sucessores - ganha um matiz histórico e sociológico que

(93) Op.cit., p. 167.

${ }^{(94)}$ Cf. supra, pp. 277 sqq. 
se dirige à acção individualizada de cada um deles, estabelece graduações e insinua paralelos, por vezes vantajosos, com a realidade grega. Daí decorrem outros juízos de valor, agora orientados por critérios pragmáticos, como seja a capacidade de coesão nacional ou uma governação sentida como (in)eficaz na esfera da sua aceitação popular.

Esta viragem torna-se em especial sensível após a expedição de tropas voluntárias gregas que, sob o comando do ateniense Xenofonte e do espartano Arcesilau, se colocaram ao serviço da facção persa comandada por Ciro-o-Moço, filho de Artaxerxes, contra seu irmão e detentor do reino. Embora esta colaboração militar tivesse como centro Esparta, é ao ateniense Xenofonte que se deve o contributo mais óbvio que o século IV a.C. assimila, relativamente à Pérsia, de uma civilização avançada e de modo algum alheia - pelo menos nas suas elites - aos valores privilegiados pela paideia grega.

Mesmo os rótulos tradicionais, apostos aos bárbaros invasores de outrora - como o servilismo perante o poder despótico ou a preocupação de alardear riquezas e fausto -, se deslocam, com um cambiante significativo, dos Persas para os Medos. Quer no elogio da kalokagathia de Ciro-o-Moço, que a Anábase figura como incarnação do ideal político e guerreiro dos Persas, quer no modelo de "educação de príncipes" que a Ciropedia difunde ${ }^{(95)}$, Xenofonte abre caminho a uma visão diversificada da Pérsia e, sobretudo, inovadora nos vários aspectos humanos em que coincide com a realidade helénica. O eco da experiência vivencial e literária de Xenofonte (que Platão, embora não cite, certamente conheceu) está presente nos escritos da última fase, onde comparecem tópicos de natureza política e sociológica - como é o caso das Leis e das Cartas VII e VIII.

Pelo que toca às Leis, a principal referência aos Persas vem na sequência de dois tipos "puros" de constituição - monarquia e democracia - que,

${ }^{(95)}$ No contexto do Nicocles (príncipe cipriota) de Isócrates e da obra platónica (em particular a República e o Alcibiades I), pode considerar-se que a Ciropedia inaugura uma modalidade literária específica, subordinada ao tópico da "educação de príncipes", que irá marcar profundamente as literaturas europeias. Uma história da projecção da obra (da qual, no dizer de Cícero, Cipião Emiliano nunca se separava - Q.fr.1.1.8.23) pode ver-se em P. Carlier, "L'idée de monarchie impériale dans la Cyropédie de Xénophon” Ktema 3 (1978)133-166 e Nair de Nazaré Castro Soares em O Príncipe ideal no século xvi e a obra de D. Jerónimo Osório (Coimbra, 1994) p. 26 e em diversos outros passos assinalados no índice. Em Xénophon, Extraits de la Cyropédie (Paris, Hachette, s/d), J. Petitjean apresenta sugestivo conjunto de apreciações sobre a influência de Xenofonte em autores latinos e franceses. 
de acordo com o Estrangeiro Ateniense, estão na origem do pensamento legislativo, traduzindo o primeiro o critério da autoridade e o segundo, o da liberdade. Os demais tipos (aristocracia, oligarquia...) são na prática formas "mistas", que têm em vista a conciliação de ambos os princípios, um e outro essenciais à estabilidade de um regime político (III, 693d-e). Entre este últimos, Platão elege a monarquia espartana, que desde início procurou a eficácia numa repartição de poderes: primeiro, com a instituição de uma diarquia; depois, com o Conselho dos Anciãos e a magistratura dos Éforos, órgãos pelos quais a vontade dos cidadãos se fazia ouvir (III, 691d-692b).

Não cabe, no âmbito deste estudo, pormenorizar as ideias mestras que, da República às Leis, passando pelo Político, alimentam em Platão as várias reflexões sobre a degenerescência dos regimes políticos. Importa, sim, salientar que, em oposição a Esparta (o único Estado que, juntamente com Creta, se manteve fiel ao primitivo ideal dórico da harmonia entre autoridade e liberdade), Atenas é posta lado a lado com a Pérsia (III, 693e-694a). Quer uma quer outra perderam-se pela pleonexia de um dos elementos referidos: a Pérsia, pelo excesso de poder concentrado no seu rei, com sacrifício total da liberdade dos cidadãos; Atenas, pelo excesso de liberdade que, em sentido contrário, criou um "vazio do poder", despojando de autoridade os seus governantes (III, 699e).

Mais curioso ainda é que o Estrangeiro Ateniense das Leis associe o esplendor que ambas no passado ostentaram à harmonia temporária entre os dois princípios. A Atenas dos antepassados, embora estruturada como democracia, era então um regime disciplinado, que reconhecia e acatava a autoridade dos seus governantes; a Pérsia, embora estruturada como monarquia, conheceu na época dos seus reis mais assinalados (Ciro-o-Antigo e Dario) a experiência avançada de uma repartição de poderes, que tinha o seu correlato na relativa liberdade (eleutheria) dos seus cidadãos, tratados em pé de igualdade e com permissão de se exprimirem francamente (parresia, 694b).

A imagem da Pérsia ideal ao tempo de Ciro, que Dario mais tarde procurou retomar ${ }^{(96)}$, lembra Atenas nos seus melhores tempos, os tempos

(96) O louvor a Dario, que reaparece na Carta VII, terá sobretudo a ver em Platão com a renúncia em assumir poderes absolutos e, eventualmente, com a imagem mítica que os Peresas de Ésquilo difundiram. As Histórias de Heródoto relativizam, nas entrelinhas, a projecção dessa imagem (para além das fracassadas campanhas na Cítia, no Líbia e na Grécia): vide $\mathbf{M}^{a}$. F. Sousa e Silva, "Dario, o Grande-Rei, personagem em Histórias de Heródoto", Mathesis 4 (1995) 63-88. 
da democracia disciplinada de Sólon ${ }^{(97)}$, que assegurou à Ática a coesão e o ímpeto indispensáveis para se posicionar como guardiã da Grécia, quer isoladamente na primeira fase das invasões (Maratona), quer em conjunto com Esparta mais tarde (Plateias).

Deixando de parte as razões da perda desse equilíbrio - genericamente atribuídas à ignorância ou falta de cultura (amathia), por imprevisão de uma paideia "educação" adequada, bem sensível nos sucessores directos de Ciro e Dario -, tem interesse observar a equidistância que o l. III das Leis traça entre Atenas e a Pérsia. O passo 693e-694a sintetiza-a com razoável eficácia, pondo ambas em confronto com Esparta e Creta:

"Uma [a Pérsia], por ter favorecido em excesso, ou como quer que seja, o princípio monárquico, e a outra [Atenas], o da liberdade, - nenhuma delas logrou o equilíbio entre ambos, enquanto os vossos Estados, o espartano e o cretense, deram a volta por cima. Os Atenienses e os Persas também a deram em tempos, mas agora estão por baixo.”

Neste volte-face, relativamente ao sentido tradicional da dicotomia grego/ bárbaro (liberdade versus escravidão) avulta a influência das monografias atrás citadas de Xenofonte, influência tanto mais perceptível quanto o louvor a Dario (695c-d) omite diplomaticamente a circunstância de ter sido ele o primeiro soberano persa a empreender as invasões à Grécia. Mesmo que haja nas entrelinhas um propósito de crítica à Ciropedia, com a demonstração da ineficácia de uma "educação de príncipes" que de nada valeu a Cambises, filho de Ciro-o-Antigo, ou a Xerxes, filho de Dario, o apreço pela Pérsia antiga e o reconhecimento de valores humanos e políticos coincidentes com os da Atenas de outrora estão indissoluvelmente ligados à nova imagem que os escritos de Xenofonte foram impondo ${ }^{(98)}$.

(97) Os oradores atenienses do final do séc. V e da $1^{\underline{a}}$ metade do séc. IV a. C. Tendem a centrar em Sólon os louros da instituição da sua democracia. Historicamente, contudo, terão sido mais decisivas as reformas de Clístenes, no início do séc. V a. C.: vide J. Ribeiro Ferreira, Participação e poder na democracia grega (Coimbra, 1990) pp. 11-41.

(98) A Pérsia que se exalta, tanto na Anábase quanto na Ciropedia, é a Pérsia Antiga, de que Ciro-o-Moço foi, para Xenofonte, o último representante e a esperança frustrada de um ressurgimento. $\mathrm{O}$ sentimento de decadência face à nação persa é comum à Grécia, com excepção de Esparta e das suas instituições, que no entanto virão a desiludi-lo também. Uma pormenorização deste posicionamento que a obra de Xenofonte transmite pode ver-se na análise de Ribeiro Ferreira sobre a Anábase e o Agesilau (op.cit., pp. 481-490), a confrontar com a visão global de Jaeger, op.cit., pp. 1141-1177 ("Xenofonte, o cavaleiro e o soldado ideais") - que eventualmente exagera o propósito crítico do l.III das Leis à Ciropedia (pp. 1253-1257). 
Reflexo concreto dessa mudança é a inclusão da cinegética, embora a título acessório, na paideia da futura cidade dos Magnetes. A arte de caça não constituía efectivamente qualquer ponto de referência na tradição educativa, quer de Espartanos quer de Atenienses; ao inseri-la nas Leis (VII, 822d-824a), embora com limitações de ordem ética a algumas das tácticas descritas por Xenofonte, Platão dá o seu aval às virtualidades educativas que o autor da Ciropedia lhe assinalara na formação dos nobres persas, e a que consagrou o tratado conhecido por Cinegético ${ }^{(99)}$.

Não representa este o único caso em que, tal como o Egipto, a Pérsia parece oferecer paradigmas à actualidade grega ou a um passado recente. Na Carta VII lamenta-se que o tirano Dionísio I de Siracusa, "sete vezes menos sábio que Dario" (332a-b), ${ }^{(100)}$ não tenha seguido o exemplo do rei persa, que soube distanciar-se da tentação do poder absoluto, repartindo-o pelos aliados da vitória e promulgando leis que asseguranssem a justiça. Em idêntico contexto, a Carta VIII regista em alternativa a atitude do rei Licurgo, o rei-legislador a quem Esparta deve a repartição do poder não só por dois reis, mas também por um Conselho de Anciãos e pela magistratura dos éforos. A proximidade entre o exemplo persa e o espartano (que a obra de Xenofonte insinua, a ponto de se falar de uma Pérsia idealizada de acordo com as práticas espartanas $\left.{ }^{(101)}\right)$ é assim o melhor testemunho de como a dicotomia grego/bárbaro, assumida sobretudo como oposição cultural e política aos invasores da Grécia, se esbate quase por completo ao longo de um século de contactos.

No caso de Platão entram ainda em jogo considerações de ordem pragmática, que a experiência siracusana acarretou. $\mathrm{O}$ reconhecimento da necessidade de um governo forte na Sicília (pelo menos enquanto os "Bárbaros", agora representados pelos Cartagineses e pelos Oscos, constituíssem ameaça ao território grego) conduz a uma distinção já sugerida mas não claramente enunciada na República, entre 'tirania' e 'monarquia':

${ }^{(99)}$ Cf. Cyr. I, 2.9-11. Remetemos para Jaeger a discussão da autoria xenofôntica do Cinegético (op.cit., p.1175 n.134).

${ }^{(100)} \mathrm{O}$ setefunciona como um número simbólico na narrativa referente a Dario em Heródoto: vide M. ${ }^{\text {a }}$ F. Sousa e Silva, no artigo citado na nota 96, p. 326. Na realidade, parecem ter sido 22 as satrapias fundadas por Dario.

(101) Vide e.g. Ph. A. Stadter, "Fictional Narrative in the Cyropedia", AJPH 112 (1991), esp. pp. 462-467, que releva também, em Xenofonte, a semelhança entre o "seu" Ciro e o Sócrates de Platão. 
a primeira é um "não-regime" que canaliza arbitrariamente as energias e os interesses do povo no proveito pessoal de um só governante; a segunda é conciliável - como vários exemplos históricos mostram, não só entre os Helenos como entre os Bárbaros - quer com uma repartição de poderes, quer com o estabelecimento de leis que que efectivamente promovam a justiça entre os cidadãos. O Político pressupõe mesmo a valorização da figura do basileus, tanto nas formas primitivas de organização social - que recordam a imagem homérica de "pastor dos povos"(102) - como no conceito lato de basileus que, em abstracto, poderá caber a qualquer governante que reuna as condições descritas.

Não é assim de estranhar que, nos conselhos aos familiares e partidários de Díon, Platão anteponha, à "tomada do poder" pelo faç̧ão democrática, a vantagem de uma conversão da tirania em realeza (eis basileian, 354a), analogamente ao que Dario fez na Pérsia e Licurgo em Esparta, onde "a lei soberana é que reinava sobre os homens e não havia homens que tiranizassem as leis" (354c-d). Não se trata já do governo do "filósofo-rei" que décadas antes alimentara, no criador da República, o sonho de implantar em Siracusa a Cidade ideal, mas antes de assegurar pragmaticamente um regime que, a par da autoridade forte do basileus (que a sobrevivência dos Gregos na ilha exigia no momento) garantisse o estabelecimento da isonomia isto é, de leis iguais para todos os cidadãos e a que essa mesma autoridade se submetesse - condição imprescindível da sobrevivência de um Estado, para Platão como para os Gregos em geral.

\section{Vias de SUPERAÇÃo dA ANTINOMIA GREGo/báRbARO}

Perante o desfazer gradual de antinomias, cabe perguntar o que permanece da oposição grego/ bárbaro, na última fase da obra platónica. Permanecem como seria de esperar, os factores pelos quais primariamente se havia definido: a língua e a raça. Mas não já, na generalidade dos casos, como oposição e sim como diferença, diferença que é também distintivo dos

(102) Na realidade, a figura do rei-pastor no Político poderá sobretudo visar o conceito de realeza entre os Persas: projectando-o na mítica Idade do Ouro, Platão considera-o inadequado às sociedades modernas, para as quais se preconiza uma repartição de poderes, embora de escolha exigente nos seus representantes. Mas a palavra para os designar pode ser a mesma (basiles). 
povos bárbaros entre si, como se aponta de forma inequívoca no passo do Político citado atrás (263c-d).

Ao longo da $1^{\underline{a}}$ metade do séc.V a.C., o incremento das relações comerciais, políticas e até turísticas com os povos da mesma área geoestratégica $^{(103)}$ (em que as colónias desempenharam parte importante) permitiu, a par da ultrapassagem de estereótipos vários, um entendimento mais flexível dos parâmetros civilizacionais que regiam as ditas sociedades bárbaras. Encontram-se mesmo paralelos insuspeitados, como se assinalou atrás a propósito de Dario e Licurgo ou, em sentido negativo, o que aproxima a tirania siciliana do despotismo dos soberanos asiáticos. Não são paralelos meramente formais, se tivermos em conta que um dos suportes basilares da dicotomia grego/ bárbaro radicava no sentimento helénico de liberdade, assente na isonomia, face à condição comum de "escravos" que, segundo os Gregos, era a dos Bárbaros sujeitos ao poder despótico de "um só”(104).

Um passo do Teeteto ilumina bem esta mudança de postura: em $175 \mathrm{c}$ o tipo genuíno do filósofo, que Sócrates pouco antes caracterizara, renuncia sem mais a questões como "saber se o (Grande-)Rei é feliz com os seus lingotes de ouro", para se concentrar na indagação do que é, de facto, "a realeza, a felicidade ou a infelicidade" e de que modo se relacionam com o ser humano. Subjacente a esta recusa de uma estereótipo, ainda bem vivo nos tempos do Górgias, está não apenas um conceito amadurecido de 'filósofo', como a consciência da indiscriminada atribuição aos Bárbaros de um conceito de felicidade alicerçado tão-só na riqueza e no poder - de que é exemplo tradicional o Grande-Rei. O filósofo avisado do Teeteto rejeita, em consequência, a discussão de quaisquer tópicos que insinuem, de perto ou de longe o rótulo de "grego" ou de "bárbaro", num domínio que é, unitariamente, o da realidade espiritual do homem.

Não estamos com isto a sobrevalorizar uma referência, aparentemente diluída num longo desfiar de situações que não implicam, em concreto, tal problemática. Que esse é o peso da referência, indica-o o passo imediatamente anterior onde as pretensões de nobreza, assentes em pergaminhos de "família" ou de "raça" (o grego designa-as ambas com o mesmo termo

(103) Para a importância do Mediterrâneo como área geo-estratégica, e preferencial nas relações sobretudo comerciais entre os povos que a habitavam, desde os tempos pré-históricos (como os actuais dados arqueológicos comprovam), veja-se o estudo de V.Jaboullie, O Mediterrâneo antigo: unidade e diversidade (Lisboa, 1996) em especial pp. 9-36.

${ }^{(104)}$ Cf. supra pp. 284 e 288 sqq. 
genos), se esfumam na evidência de milhares de antepassados comuns que cada homem tem e que são a parte maior da história da humanidade:

\begin{abstract}
"No que toca a genealogias, se ouve tecer loas à nobreza de alguém que pode averbar sete avós ricos na família, cheira-lhe logo a gente embotada, de vistas curtas, a quem a ausência de princípios impede de fixar os olhos no conjunto e reflectir que, quanto a avós e bisavós, todos os temos aos milhares, em número infindável, e que cada um destes conta com muitos milhares de outros, entre pobre e ricos, reis e escravos, bárbaros e helenos ...” (174e-175a).
\end{abstract}

Este passo, já famoso na Antiguidade, a que Popper - o mais exaustivo crítico da Cidade platónica - presta incondicional homenagem ${ }^{(105)}$, está no cerne de um projecto "libertário" de vivência filosófica, em que radica a meditação do Político sobre 'a realeza' (basileia). Num tema que apela candentemente para a distinção que os Gregos foram desenvolvendo entre os seus pressupostos de organização social e os dos regimes bárbaros, não há sequer ocorrências nominais de Barbaroi. A imagem do basileus (o filósofo/rei da República), laboriosamente construída a partir da reflexão sobre os estádios primitivos de organização social, desliga-se ostensivamente dos paradigmas históricos ou contemporâneos tradicionais.

Não obstante o clímax desta "filosofia das alturas", como o Sócrates do Teeteto não se coíbe de a designar (175d, 176a-b) ${ }^{(106)}$, os "Bárbaros" na sua

(105) Op. cit., p. 281. O passo constitui a única excepção ao que, para Popper, representa univocamente em Platão "hostility towards the humanitarian idea of unity of mankind which transcends race and class”. A ausência absoluta de sentido do diálogo platónico como obra dramática e a omissão de outras que falam uma linguagem bem diversa da República, leva Popper a uma forçada atribuição do passo citado ao Sócrates histórico, devendo o Teeteto situar-se no período dos diálogos ditos "socráticos", anteriores à República. Essa óbvia arbitrariedade está em total desacordo com o que a análise de estilo e de conteúdo permite deduzir: veja-se e.g. o nosso estudo "Da maiêutica socrática à maiêutica platónica", Humanitas 55 (2003) 265-281, esp. pp. 275-279.

De salientar, de resto, com M. Cornford (Plato's Theory of Knowledge, London 1973, reimpr. de 1935, pp. 88-89), o distanciamento sensível do Sócrates histórico neste imagem de filósofo - mais afim ao Cinismo - que não só despreza ostensivamente riquezas e preocupações genealógicas mas também recusa participar em banquetes e não conhece sequer "o caminho da praça pública” (173d) ...

(106) Desde Plotino (Enn.1.2) o passo tem sido enfatizado como paradigma da "vida contemplativa" do filósofo em oposição à "vida activa" e posto em paralelo com a Alegoria da Caverna no livro VI da República. Sobre essa interpretação, e outras possíveis, da digressão do Teeteto, cf. M. Burnyat, Introduction au Théétète de Platon (trad. francesa) (Paris, 1998) pp. 51-60. 
conotação política mais comum - os Bárbaros agressores, que constituem a cada passo ameaça vital aos valores civilizacionais e espirituais conquistados pelos Gregos - não desaparecem no horizonte da obra platónica. O lugar comummente atribuído aos Persas é agora preenchido pelos Cartagineses (Karkhedonioi) e pelo povo designado por Opikoi, que tudo indica tratar-se dos Oscos. São eles que, na $1^{\underline{a}}$ metade do séc. IV a.C., põem em perigo o mundo helénico representado pelas cidades do sul de Itália e particularmente (pelo que toca aos Cartagineses) pelas da Sicília.

A linguagem antiga, que apela com veemência para a unidade de todos os Gregos, sob pena de se tornarem presa fácil dos Bárbaros, ressurge nas Cartas VII e VIII, transmitindo o eco de uma vivência dramática e sentida in loco. De assinalar, como lembrámos atrás, o clima de permanente assédio militar por parte dos Cartagineses, que a deposição de Dionísio II de Siracusa acentua, suscitando o receio último de que todo o território da Sicília fique "privado da língua grega" (353e).

As ambições imperialistas dos Bárbaros sobre a Hélade, que levaram outrora os Persas a invadir o continente grego, renascem agora sob a égide de Cartago. É uma ameaça cíclica de que Platão se dá conta, nos regimes severamente defensivos que prevê na República e nas Leis. Mas nesta última obra - onde xenos comporta por vezes uma acepção indiferenciada de estrageiro "grego" e "não grego", à semelhança do adjectivo othneios - parece ganhar visibilidade a importância dos laços diplomáticos que o passo 729a729e subentendem, a propósito do respeito "sagrado" que é devido aos estrangeiros e aos contratos com eles assumidos.

Foi afinal a dinâmica da diplomacia com o Grande-Rei que permitiu consolidar as vitórias de Maratona, Salamina e Plateias. Ao longo do séc. $\mathrm{V}$ a.C., o conhecimento e a aceitação mútua de padrões civilizacionais diversos, que foram ganhando "simpatizantes dos Gregos" (philellenes) entre os Bárbaros, tal como "simpatizantes dos Bárbaros" (philobarbaroi) entre os Gregos, contribuiram não só para um alargamento de horizontes civilizacionais, patentes nos últimos diálogos platónicos, mas também para a diluição dos propósitos expansionistas Grande-Rei.

Um eco subtil da conscencialização dessa realidade - que uma provável viagem ao Egipto poderá ter despontado - é a referência ocasional, nos últimos diálogos, ao hermeneus "intérprete", circunscrito, nos diálogos anteriores, à esfera religiosa (e.g. Íon 535a, Symp. 202e). A sua função corrente de "assessor" de um intercâmbio linguístico, que viabiliza e 
estimula as relações entre povos de línguas diversas, só agora se insinua no texto filosófico de Platão ${ }^{(107)}$. No Teeteto, a autoridade do hermeneus surge a par da do grammatistes, no que toca à compreensão dos sons que em princípio fazem sentido numa língua; e a possibilidade de, através dela, se estabelecer um "diálogo filosófico" numa língua bárbara (recusada in limine no Ménon $\left.{ }^{(108)}\right)$ aparece configurada, ainda que remotamente, no Filebo 16c, ao frisar-se a exuberância com que o "amigo de prazer" se entrega a tópicos da sua predilecção:

"O seu entusiasmo pela discussão é tal que não pouparia ninguém - nem mesmo um Bárbaro, se tivesse à mão um intérprete!”

É a passagem, directa ou mediada, de uma língua a outra que permite o reconhecimento, noutras civilizações, de realidades escondidas sob nomes diversos que se tornam próximas, quando não identificáveis, no acto recíproco de compreender inerente ao intercâmbio linguístico. Essa possibilidade - e necessidade - é simbolizada no Crítias ao nível mais elementar dos "nomes" (onomata) quando, a pedido de Sólon, os sacerdotes de Sais "traduzem" para ele os nomes "atlantes", ligados à fundação de Atlântida, que os seus ancestrais haviam, por sua vez, traduzido para egípcio $(113 \mathrm{a})^{(109)}$. Conquanto se não refira o termo hermeneus, o passo que introduz a narrativa de Atlântida não é menos significativo quanto à importância sentida na sua função, na partilha de um presente, como de um passado comum - aqui representado na história mítica de Atenas e Sais.

(107) Sobre o destaque em Heródoto da pessoa do intérprete veja-se Cármen Soares, "A língua, um instrumento de diálogo cultural em Heródoto", Biblos 1 (2ª́ série) 13-22, que analisa vários exemplos ilustrativos, não apenas do recurso a intérpretes (que tanto Gregos como Bárbaros procuravam formar, pondo crianças e jovens a aprender línguas estrangeiras), mas também de casos de bilinguismo com crianças nascidas de progenitores de diferentes raças e línguas.

(108) Cf. supra p. 268. O escravo que Ménon "empresta" a Sócrates para realizar o teste da anamnese só é aceite por Sócrates após saber que "fala grego" (condição sine qua non). Na realidade, embora provavelmente de origem bárbara, trata-se de um escravo que nasceu já em casa de Ménon.

(109) Cf. supra n. 7, p. 270. 


\section{Série}

\section{Documentos}

Imprensa da Universidade de Coimbra

Coimbra University Press

2005

- U

C - 